\title{
KONTROVERSI 'AUL DALAM HUKUM WARIS ISLAM DAN PRAKTIKNYA DI INDONESIA
}

\section{THE 'AUL CONTROVERSY IN ISLAMIC INHERINTANCE LAW AND PRACTICES IN INDONESIA}

\author{
Kasman Bakry \\ Sekolah Tinggi Ilmu Islam dan Bahasa Arab (STIBA) Makassar \\ Email: kasmanbakry@stiba.ac.id \\ Muhammad Nirwan Idris \\ Sekolah Tinggi Ilmu Islam dan Bahasa Arab (STIBA) Makassar \\ Email: muhammadnirwanidris@stiba.ac.id

\section{Fadlan Akbar} \\ Sekolah Tinggi Ilmu Islam dan Bahasa Arab (STIBA) Makassar \\ Email: fadlanakbar@stiba.ac.id

\section{Kurnaemi Anita} \\ Sekolah Tinggi Ilmu Islam dan Bahasa Arab (STIBA) Makassar \\ Email: kurnaemia@stiba.ac.id
}

\section{Keywords : \\ Comparative, Farāid,} Islamic Law
This study aims to uncover the controversy of 'aul in the concept of Islamic inheritance' and the method of the majority of scholars in tarjīh this problem and how it is practiced in Indonesia. This research is a qualitativeresearch with a normative juridical approach that focuses on literature review and comparative analysis. The results of the study found that 'Umar bin al-Khattāa b viewed that the concept of 'aul was a solution to the problem of inheritance which experienced an increase or excess in the origin of the problem which was not sufficiently divided among all heirs. As for 'Abdullah bin 'Abbās mentioned that if the inheritance is not enough to be distributed to all the heirs, then the one who has the strongest position among the heirs will take precedence over the inheritance rights. The majority of scholars then determined the solution to the inheritance problem that experienced 'aul by interpreting the words of 'Umar bin al-Khattāa, namely using the concept of 'aul. Then it was found that the application of the problem of 'aul in inheritance in Indonesia is considered still not optimal and even barely implemented. This is triggered by several factors including not too interested in the community and not yet aware of the importance of applying sharia law in inheritance issues. This research is expected to contribute thinking and education as a complement and valuable solution for inheritance problems in the Muslim community.

\section{Kata kunci :}

\section{ABSTRAK}

Komparatif, Farāid, Hukum Islam
Penelitian ini bertujuan untuk mengungkap kontroversi 'aul dalam konsep kewarisan Islam dan metode jumhur ulama dalam men-tarjīh permasalahan ini serta bagaimana praktiknya di Indonesia. Penelitian 


\begin{abstract}
ini merupakan penelitian kualitatif dengan pendekatan yuridis normatif yang fokus pada kajian literatur dan analisis komparatif. Hasil penelitian menemukan bahwa 'Umar bin al-Khaț̣āb memandang bahwa konsep 'aul adalah solusi bagi masalah warisan yang mengalami kenaikan atau kelebihan pada asal masalah yang tidak cukup dibagi kepada seluruh ahli waris. Adapun 'Abdullah bin 'Abbās menyebutkan bahwa apabila harta warisan tidak cukup untuk dibagikan kepada seluruh ahli waris maka yang memiliki kedudukan paling kuat diantara ahli waris tersebut akan didahulukan haknya dari harta warisan. Jumhur kemudian menetapkan solusi pada permasalahan warisan yang mengalami 'aul dengan men-tarjīh perkataan 'Umar bin al-Khaț̣āb yaitu menggunakan konsep 'aul. Kemudian ditemukan ditemukan bahwa penerapan masalah 'aul dalam kewarisan di Indonesia dinilai masih belum maksimal bahkan nyaris tidak terlaksana. Hal ini dipicu oleh beberapa faktor diantaranya tidak terlalu minatnya masyarakat dan belum sadar akan pentingnya penerapan hukum syariat dalam masalah kewarisan. Penelitian ini diharapkan dapat memberikan kontribusi pemikiran dan edukasi sebagai bahan penyempurna dan solusi berharga bagi permasalahan kewarisan di tengah masyarakat muslim.
\end{abstract}

Diterima: 27 September 2021; Direvisi: 15 November 2021; Disetujui: 7 Desember 2021 Tersedia online: 10 Desember 2021

How to cite: Kurnaemi Anita, Kasman Bakry, Muhammad Nirwan Idris, Fadlan Akbar, "Kontroversi 'Aul dalam Hukum Waris Islam dan Praktiknya di Indonesia", NUKHBATUL 'ULUM: Jurnal Bidang Kajian Islam Vol. 7, No. 2 (2021): 211-235. doi: 10.36701/nukhbah.v7i2.423.

\title{
PENDAHULUAN
}

Kewarisan menempati kedudukan yang tinggi dalam Islam dan menjadi satusatunya syariat yang dijelaskan pembagiannya secara rinci oleh Allah swt. dalam AlQur'an, tanpa mengembalikan atau mendelegasikan urusan tersebut kepada para pemimpin termasuk Nabi saw. Masalah yang telah dirinci dalam Al-Qur'an ini dikenal sebagai ilmu mawārīs atau ilmu farāiộ ${ }^{1}$ yaitu ilmu untuk mengetahui bagaimana pembagian harta warisan kepada orang yang berhak menerimanya. Kedudukan masalah ini mendapat perhatian yang besar dalam Islam, dibuktikan dengan beberapa hadis Nabi saw. yang menjelaskan tentang pentingnya mempelajari ilmu mawārìs. ${ }^{2}$ Bahkan terdapat penjelasan dalam Al-Qur'an bahwa siapa yang melaksanakan ketentuan pembagian warisan sesuai ketentuan Allah swt. termasuk hamba yang taat dan dijanjikan oleh Allah swt. dengan surga. Sebaliknya, bagi yang tidak melaksanakan ketentuan pembagian warisan sebagaimana disebutkan dalam AlQur'an termasuk orang yang durhaka kepada Allah swt. dan rasul-Nya dan diancam dengan neraka. ${ }^{3}$

1 Șaleh bin Faūzan bin Abdillah Al-Faūzan, Al-Taḥqūqātu al-Marḍiyyah Fi al-Mabāḥiś alFarḍiyyah, Cet. I (Riyad: Maktabatu al-Ma'ārif li al-Nasyri wa al-taūzì’, 1999), h. 13.

${ }_{2}^{2}$ Muḥammad 'Alī Al-Ṣābūn̄̄, Al-Mawārī̀s Fì Al-Syarī'ati Al-Islāmiyyati, Cet. I (Kairo: al-Dār al'Alamiyyah, 2016), h. 10.

${ }^{3}$ Al-Faūzan, Al-Taḥqūqātu Al-Marḍiyyah Fi Al-Mabāhỉs Al-Farḍiyyah, h. 14. 
Sakralitas kewarisan Islam sebagaimana yang telah disebutkan, membuat ahli fikih terkesan mengambil langkah hati-hati dalam menyelesaikan kasus waris, khususnya dalam kasus-kasus baru yang belum pernah terjadi di masa Nabi saw., sementara tidak disebutkan ketentuan pemecahannya dalam Al-Qur'an. Untuk melestarikan dan memastikan berjalannya ajaran agama dengan baik, manusia diperintahkan menggunakan akalnya sebagai alat untuk berijtihad atau upaya yang dilakukan dengan penuh kesadaran dan kehati-hatian untuk mencari solusi atas berbagai persoalan kehidupan. ${ }^{4}$

Di sisi lain, teks Al-Qur'an sebenarnya sudah menjelaskan secara rinci konsep dasar pembagian warisan secara detail. Meskipun demikian, terdapat beberapa permasalahan yang kemudian muncul dan tidak ditemukan cara penyelesaiannya dalam Al-Qur'an dan hadis walaupun jumlahnya tidak banyak dibanding masalah khilafiyah yang ada pada disiplin ilmu fikih yang lain. Oleh karena itu, ulama mengambil jalan ijtihad untuk memecahkan masalah-masalah tersebut. ${ }^{5}$

Salah satu kasus yang menimbulkan kehati-hatian dalam penyelesaiannya adalah masalah 'aul. ${ }^{\text {' }}$ Aul merupakan salah satu dari beberapa permasalahan yang tidak ditemukan penyelesaiannya dalam Al-Qur'an. Pada masa awal turunnya risalah Islam hingga pada masa pemerintahan kekhalifahan Abu Bakar al-Șiddīq, perkara 'aul atau adanya penambahan asal masalah dalam masalah waris tidak pernah terjadi. Kasus 'aul untuk pertama kali terjadi pada masa pemerintahan ke khalifahan kedua yaitu khalifah Umar bin al-Khațāa dan beliau sendiri sebagai pemecah masalah tersebut. ${ }^{7}$

'Aul adalah bertambahnya jumlah sihām dan kurangnya bagian waris. ${ }^{8}$ Permasalahan yang pertama kali didapat di zaman Umar bin al-Khaț̣āb yaitu adanya seorang wanita wafat dan meninggalkan suami dan dua saudara perempuan sekandung, dimana Allah swt. telah menetapkan bagian 1/2 untuk suami dan 2/3 untuk dua saudara perempuan sekandung. Apabila pembagian warisan dimulai dari suami maka hak untuk dua saudara perempuan sekandung tidak terpenuhi, namun bila pembagian warisan dimulai dari dua saudara perempuan sekandung maka hak untuk suami tidak terpenuhi.

Berangkat dari masalah tersebut 'Umar bin al-Khattāb mengambil jalan ijtihad untuk menyelesaikan masalah dengan menggunakan metode 'aul, dengan mengkiaskannya ke utang. ${ }^{9}$ Seluruh sahabat sepakat dengan penggunaan 'aul di zaman Umar bin al-Khattāb termasuk 'Abdullah bin 'Abbās. Permasalahan baru muncul setelah wafatnya Umar bin al-Khaț̣āb dimana 'Abdullah bin 'Abbās menyilisihi penerapan 'aul yang sudah disepakati sehingga masalah ini menjadi kajian khusus di

\footnotetext{
4 'Abdul 'Aziz al-Said, Al-Ijtihad Wa Ri'ayat Al-Mașlaḥặ, Cet. I (Riyad: Islamic University of IMBS Press, 1994), h. 24.

5 Syabbul Bachri, "Pro Kontra 'Aul Dalam Kewarisan Islam: Studi Komparatif Antara Pandangan Sunni Dan Syiah," Journal de Jure 10, no. 2 (December 30, 2018): 52, doi:10.18860/JFSH.V10I2.6707.

${ }^{6}$ Sayyid Muhammad Husaīn Faḍlullah, Fiqh Al-Mawārīs Wa Al-Farāiḍ, Juz 1 (Libanon: DārulMalāk, 2000), h. 108.

${ }^{7}$ Al-Faūzan, Al-Taḥīqātu Al-Marḍiyyah Fi Al-Mabāhịis Al-Farḍiyyah, h. 166.

8 Mannā' Al-Qaț̣āan, Tarikh Al-Tasyri' Al-Islāmī Al-Tasyri' Wa Al-Fiqh, Cet. IV (Riyad: Maktabatu al-Ma'ārif li al-Nasyri wa al-taūzī’, 2012), h. 217.

${ }^{9}$ Al-Faūzan, Al-Taḥqūqātu Al-Marḍiyyah Fi Al-Mabāḥis Al-Farḍiyyah, h. 167.
} 
kalangan ulama, bukan dari sisi kesepakatan konsep 'aul yang sudah terjadi, akan tetapi dari sisi metode yang ditawarkan 'Abdullah bin 'Abbās dalam persoalan ini. ${ }^{10}$ Kajian ini menjadi penting untuk dibahas karena akan menjadi rujukan bagi seluruh muslim di seluruh negara Islam.

Di Indonesia sendiri berlaku sistem penyelesaian masalah kewarisan dengan mengacu kepada hukum Islam, hukum perdata (barat), dan hukum adat. Untuk kewarisan di luar beragama Islam tunduk kepada Kitab Undang-Undang Hukum Perdata (KUHP), sedangkan yang beragama Islam merujuk kepada kumpulan aturan hukum Islam yang di dalamnya terdapat aturan kewarisan. ${ }^{11}$ Lebih jauh, Syaifullah mengungkapkan bahwa hukum kewarisan yang ada dan berlaku di Indonesia sampai saat ini masih belum merupakan unifikasi hukum. Pluralistiknya sistem hukum waris di Indonesia tidak hanya karena beragamnya sistem kekeluargaan adat, tetapi juga karena adanya tiga sistem hukum lain, yaitu sistem hukum kewarisan Islam yang berdasar dan bersumber pada kitab suci Al- Qur'an dan hukum kewarisan Perdata Barat yang bersumber pada Burgerlijk Wetboek (selanjutnya disebut KUHP) dan sistem hukum kewarisan adat yang bersumber pada kebiasaan atau adat yang ada di masyarakat. ${ }^{12}$

Secara legal-formal, di Indonesia dikenal istilah hak opsi yaitu hak untuk memilih bagi umat Islam untuk menyelesaikan masalah warisan ke Pengadilan Agama yang menggunakan hukum Islam atau ke Pengadilan Negeri yang mengadopsi hukum perdata Romawi. Dengan adanya hak opsi tersebut dalam realitas kehidupan umat Islam, ternyata masih banyak mereka yang menyelesaikan permasalahan waris mereka ke pengadilan Negeri. Demikian juga dalam praktik secara kultural, masyarakat Islam masih banyak yang lebih mengutamakan pembagian waris dengan merujuk kepada hukum adat, sekalipun dalam masyarakat yang secara sosiologis adalah bukan masyarakat adat dengan bentuknya yang masih kuat. ${ }^{13}$

Sebagaimana realitas yang terjadi di masyarakat Indonesia, hukum waris Islam menjadi hukum yang kurang diminati dan jarang dijadikan sebagai sumber rujukan. Fenomena tersebut sesuai dengan yang telah diberitakan Nabi saw. dari hadis yang diriwayatkan sahabat Abu Hurairah.

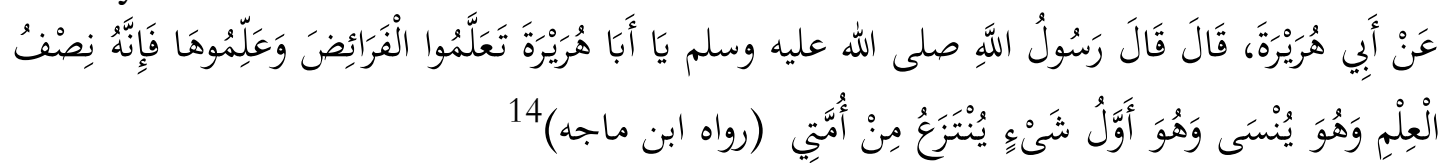

Artinya:

Dari Abi Hurāirah, bahwa Rasūlullah saw. bersabda, "Belajarlah ilmu farāiḍ dan ajarkanlah, karena sesungguhnya ia adalah setengah dari ilmu. Dan ilmu

${ }^{10}$ Al-Șābūn̄̄, Al-Mawārī̉s F̄̄ Al-Syarī’ati Al-Islāmiyyati, h. 97.

${ }^{11}$ Hulia Syahendra, “Aul Dalam Teori Dan Praktek Hukum Waris Islam,” Jurnal Hukum Replik 6, no. 1 (March 1, 2018): 119, doi:10.31000/JHR.V6I1.1179.

${ }_{12}$ Muhamad Syaifullah et al., "Pengalihan Atas Harta Warisan Di Indonesia," DiH; Jurnal Ilmu Hukum 16, no. 2 (Agustus, 2020): 179, doi:https://10.30996/dih.v16i2.3345.

13 Muhammad Firdaus, "Pembaharuan Hukum Waris Islam Di Era Kontemporer," Istinbath: Jurnal Hukum Islam IAIN Mataram 14, no. 1 (Juni, 2015): 115, doi:10.15408/istinbath.v17i1.8094.

${ }^{14}$ Abū Abdillah Muhammad bin Yazīd Ibnu Mājah Al-Qazwīn̄i, Sunan Ibnu Mājah, Cet. I (Riyad: Maktabatul Ma'arif Jauzi, 2017), h. 462. 
itu akan dilupakan dan dia adalah ilmu yang pertama kali dicabut dari umatku."

Ada beberapa perkataan ulama yang sejalan dengan hadis di atas, salah satunya adalah perkataan Abdu al-'Azīz bin 'Abdillah bin Bāz dalam kitabnya yang mengatakan,

Artinya:

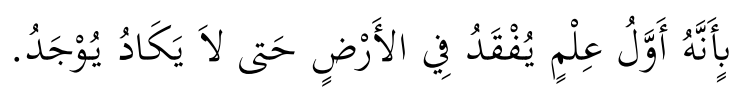

Ilmu farāid adalah ilmu pertama yang dihilangkan dimuka bumi, bahkan keberadaan ilmu farāid hampir tidak ditemukan sama sekali. ${ }^{15}$

Berdasarkan uraian di atas, artikel ini akan mengungkap kontroversi yang terdapat pada permasalahan 'aul dalam hukum waris Islam antara pendapat 'Umar bin al-Khattāb dan 'Abdullah bin 'Abbās, dengan konsep rumusan masalah sebagai berikut: (1) bagaimana konsep 'aul menurut 'Umar bin al-Khaț̣āb dan 'Abdullah bin 'Abbās?; (2) bagaimana metode jumhur ulama dalam men-tarjīh masalah 'aul?; dan (3) bagaimana realitas penerapan 'aul di Indonesia? Untuk itu, penelitian ini bertujuan untuk mengungkap kontroversi 'aul dalam konsep kewarisan Islam dan metode jumhur ulama dalam men-tarjīh permasalahan ini serta bagaimana praktiknya di Indonesia. Penelitian ini merupakan penelitian kualitatif dengan pendekatan yuridis normatif, yaitu pendekatan yang diartikan dengan hal-hal yang mengikuti aturan atau norma ajaran Islam dan memandang masalah dari apa yang tertera dalam teks $\mathrm{Al}$ Qur'an dan hadis. ${ }^{16}$

Penelitian khusus tentang kontroversi 'aul dalam kewarisan Islam dan metode ulama dalam mengeluarkan tarjīh dalam masalah ini masih terbilang terbatas sehingga penelitian ini mencoba mengkaji lebih rinci dari apa yang telah dikemukakan dalam penelitian sebelumnya. Di antaranya kajian yang dilakukan Fahḍ bin 'Abdirrahman al-Yahia yang membahas kasus 'aul dalam perbincangan para fuqahā, perbedaan pendapat para ulama dan ijmak kaum muslimin di dalamnya. ${ }^{17}$ Demikian juga penelitian yang dilakukan oleh Bachri tentang kajian komparatif antara jumhur ulama ahlu sunah dan Syiah dalam menyelesaikan permasalahan 'aul, serta penjelasan mengenai hal yang melatarbelakangi pandangan keduanya. ${ }^{18}$

Penelitian serupa juga dilakukan oleh Fitriyati yang di dalalamnya membahas secara khusus bagaimana kedudukan'așabah jika terjadi 'aul dalam kewarisan menurut 'Abdullah bin 'Abbās, ${ }^{19}$ dan penelitian oleh Syaifullah tentang pengalihan atas harta warisan yang biasa terjadi di tengah masyarakat sebelum pembagian. Dalam penelitiannya, Syaifullah menyimpulkan bahwa pembagian itu diselenggarakan dengan pemufakatan atau atas kehendak bersama di mana bila harta peninggalan

\footnotetext{
15 'Abdu al-'Azīz bin 'Abdillah bin Bāz, Matan Al-Rahbiyyah Li Al-Imām Al-Rahbī Wa Fawāid Al-Jaliyyah F̄̄ Al-Mabāhisisi Al- Farḍiyyah, Cet. V (Riyad: al-Riāsatu al- 'Āmma li al- Idārāti al-Buhus al- 'Ilmiyyah wa al-Iftāu wa al-Da'watu wa al-Irsyād, 1987), h. 5.

${ }^{16}$ Supiana, Metodologi Studi Islam, Cet. I (Bandung: PT. Remaja Rosdakarya, 2017), h. 83.

${ }^{17}$ Fahd bin Abdirrahman Yahia, “Al-'Aul F̄̄ Al-Farāiḍ Fiqhan Wa Hisāban,” Qassim UniversitySaudi Arabia 6, no. 2 (n.d.): 103, https\%3A\%2F\%2Fiefpedia.com\%2Farab\%2Fwp.

${ }^{18}$ Bachri, "Pro Kontra 'Aul Dalam Kewarisan Islam: Studi Komparatif Antara Pandangan Sunni Dan Syiah. ": 53.

19 Yusida Fitriyati, "Kedudukan Ashabah Dalam Kasus "Aul Menurut Ibnu Abbas," Nurani: Jurnal Kajian Syari'ah Dan Masyarakat 14, no. 2 (2014): 10, doi:10.19109/NURANI.V14I2.106.
} 
tersebut dibagi antara para ahli waris, maka pembagian itu biasanya berjalan secara rukun dalam suasana ramah tamah. ${ }^{20}$ Adapun kajian dalam artikel ini secara rinci menjabarkan kontroversi pendapat 'Abdullah bin 'Abbas yang menyelisihi pendapat jumhur sahabat dalam masalah 'aul. Kemudian menganalisis bagaimana masalah ini dipraktikkan di Indonesia.

\section{PEMBAHASAN}

\section{Definisi dan Sejarah 'Aul dalam Kewarisan Islam}

'Aul menurut bahasa memiliki beberapa pengertian, di antaranya 'aul berasal

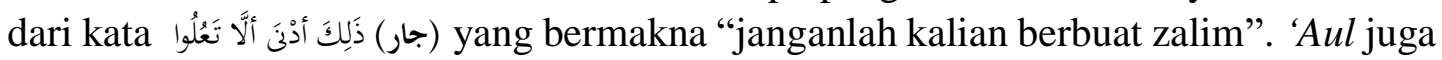
berasal dari kata النقصان yang berarti kekurangan. ${ }^{21}$ Adapun menurut istilah, 'aul memiliki beberapa pengertian berdasarkan arah pandang dari setiap mazhab. Menurut mazhab Malikiyyah, 'aul adalah bertambahnya jumlah sihām dan berkurangnya jumlah warisan untuk para ahli waris, dimana 'aul tidak masuk pada semua asal masalah, akan tetapi 'aul hanya masuk pada tiga asal masalah saja diantaranya asal masalah 6, 12, dan 24. Apabila jumlah sihām bertambah melebihi asal masalah maka terjadilah 'aul dan bisa mengurangi jumlah warisan semua ahlul furü.$^{22}$ Adapun pengertian 'aul menurut mazhab Syafi'iyyah adalah bertambahnya jumlah sihām dan berkurangnya jumlah warisan untuk para ahli waris sesuai yang telah disepakati para sahabat. ${ }^{23}$ 'Aul adalah naiknya jumlah sihām disebabkan banyaknya jumlah ahlu furū sehingga berkurangnya jumlah warisan yang didapat sesuai ketentuannya. ${ }^{24}$

Menurut mazhab Hanafiyyah, 'aul secara istilah adalah bertambahnya jumlah sihām ahlul furūḍ yang berdampak berkurangnya jumlah warisan yang didapat, sehingga pada keadaan ini ahlul furū tetapi ada pengurangan pada bagian warisan yang didapat. Ini merupakan pendapat para jumhur fuqahā dalam menyelesaikan permasalahan 'aul yang mengibaratkan masalah ini seperti utang, dimana bila jumlah harta yang dimiliki tidak mencukupi jumlah utang, maka harta tersebut dibagi rata berdasarkan jumlah utang yang dimiliki. ${ }^{25}$ Adapun menurut mazhab Hanabilah, 'aul adalah suatu keadaan di mana jumlah ahlul furụ̄ melebihi asal masalah, ${ }^{26}$ atau diartikan sebagai suatu kondisi dimana banyaknya jumlah ahlu furūẹ tidak sesuai dengan banyaknya harta warisan, sehingga perlu suatu solusi agar tiap ahli waris bisa mendapatkan bagiannya dengan adil. ${ }^{27}$ Ahmad juga menambahkan bahwa 'aul hanya bisa terjadi dengan kehadiran

\footnotetext{
${ }^{20}$ Syaifullah et al., "Pengalihan Atas Harta Warisan Di Indonesia. ”: 189.

${ }^{21}$ Ibnu Manzūur, Lisānu Al-Arab, Juz. 1 (Kairo: Dār al-Ma'ārif, 1999), h. 3175.

${ }^{22}$ Syamsuddīn Muhammad 'Arafah al-Dasūqī, Hāsyiyatu Al-Dasūqī 'ala Al-Syarḥi Al-Kabīr, Cet. I (Damaskus: Dāru ihyā al-kitab al-‘Arabiyyah, 2002), h. 471.

23 "Abdurraḥmān bin Ahmad Ibnu Qudamah Al-Maqdis̄i, Al-Syarh Al-Kabīr "Ala Matan AlMuqni, ’ Cet. I (Damaskus: Dār al-Kitāb al-`Arabī, 1989), h. 67-68.

${ }^{24}$ Abū zakariyā al-Nawawī Al-Damasyqī, Raudatu Al-Tạlibìn, Cet. I (Libanon: Dār Ibn Hazm, 2002), h. 1022.

${ }^{25}$ Muhammad Al-Hașkafī, Al-Dār Al-Mukhtār, Cet. I (Libanon: Dār al-Kutub al- 'Ilmiyyah, 2002), h. 766 .

26 'Abdullah bin Aḥmad bin Qudāmaḥ al-Hanbalī Al-Maqdis̄̄, Al-Mugnī, Cet. I (Arab Saudi: Dār 'Alam al-Kutub, 1997), h. 35.

${ }^{27}$ Al-Maqdisī, Al-Syarh Al-Kabīr "Ala Matan Al-Muqni. ”, h. 68.
} 
suami atau istri bersama ahli waris lainnya dalam satu masalah. Apabila tidak terdapat suami atau istri dalam suatu rumpun ahli waris maka 'aul tidak terjadi. ${ }^{28}$

'Aul pertama kali terjadi pada masa khalifah 'Umar bin al-Khatțāb ketika dihadapkan dengan kasus kewarisan antara suami dan dua saudari perempuan. ${ }^{29}$ Adapun Khairi menyatakan bahwa kasus yang pertama adalah tentang kewarisan suami bersama saudari kandung dan ibu..$^{30}$ Dalam kasus suami bersama dua saudari, menurut ketentuan dasar Al-Qur'an suami akan mendapatkan 1/2 dari harta kewarisan jika tidak ada anak (Q.S. al-Nisa' (4):12). Sementara itu, bagian saudari apabila lebih dari seorang adalah 2/3(Q.S. al-Nisa': (4): 176). Kondisi tersebut berimplikasi pada bagian mereka jika dijumlahkan akan menjadi 7/6, sehingga dapat dikatakan jumlah keseluruhan dari bagian ahli waris melebihi dari harta waris yang akan dibagikan. ${ }^{31}$

Jika harta yang ditinggalkan semisal Rp42.000.000,00 maka bagian suami adalah 3/6 dari $\mathrm{Rp} 42.000 .000,00$ yaitu $\mathrm{Rp} 21.000 .000,00$ Sementara bagian dua saudari adalah 4/6 dari Rp42.000.000,00 yaitu Rp28.000.000,00 Jika tiap ahli waris diberi bagian sesuai haknya maka terjadi kekurangan harta yang tersedia dari warisan sebesar Rp7.000.000,00.

Tabel 1

Konfigurasi Masalah 'Aul

\begin{tabular}{cccc}
\hline Ahli Waris & $\begin{array}{c}\text { Bagian dari } \\
\text { warisan }\end{array}$ & $\begin{array}{c}\text { Asal masalah } \\
(6)\end{array}$ & $\begin{array}{c}\text { Harta Warisan } \\
(\mathrm{Rp} 42.000,00)\end{array}$ \\
\hline Suami & $1 / 2$ & 3 & Rp21.000,00 \\
\hline 2 Saudari & $2 / 3$ & 4 & Rp28.000,00 \\
\hline & Jumlah & 7 & Rp49.000,00 \\
\hline
\end{tabular}

Sumber: Data diolah (2021)

Menghadapi masalah tersebut, 'Umar bin al-Khațtab sangat berhati-hati mengenai siapa yang didahulukan untuk mendapat bagian fard (bagian pasti yang sudah ditentukan dalam Al-Qur'an) dan siapa yang harus diakhirkan dengan mendapat pengurangan bagian fard setelah dikurangi oleh pihak yang didahulukan. Olehnya, 'Umar bin al-Khațab mengumpulkan para sahabat yang dianggap mampu menyeselesaikan permasalahan ini melalui musyawarah. ${ }^{32}$ Dalam suatu riwayat dikatakan bahwa 'Umar bin al- Khațạāb berkata,

${ }^{28}$ Zafr Ahmad al-'Uṡmān̄̄ al-Tahānawiyyu, I’lau Sunan, Juz 18, Cet. III (Idārah al-Qurān wa al'Ulūm al-Islāmiyyah, 1993), h. 402.

${ }^{29}$ Sayyid Sabiq, Fiqh Al-Sunah, Juz 3, Cet. I (Libanon: Dār al Kitāb al 'Arabī, 1997), h. 633.

30 Muhammad Khairi, 'Ilm Al-Farāiọ Wa-Al-Mawariș: Fi Al-Syari'ah Al-Islamiyyah Wa-AlQanūn Al-Suri, Ma'a Amțilah Wa-Masā’il 'amaliyah, Cet. I (Damaskus, 1978), h. 231.

${ }^{31}$ Dalam kasus suami bersama saudari kandung dan ibu, maka ketentuan nas dalam al-Quran adalah suami mendapat $1 / 2$ (Q.S. al Nisa' (4):12), seorang saudari kandung mendapat $1 / 2$ (Q.S. al Nisa': (4): 176) dan ibu mendapat 1/3(Q.S. al Nisa' (4):11). Jika dijumlahkan maka jumlah seluruh bagian mereka adalah 8/6. Sehingga harta waris akan kurang 2/6 untuk dibagikan kepada ahli waris.

32 'Abdul Hakīm Hamādah, Al-Jāmi' Lil Ahkām Al-Fiqh 'Alā Al-Mazāhib Al-Arba'ah, Cet. I (Libanon: Dār al-Kutub al- 'Ilmiyyah, 2000), h. 302. 


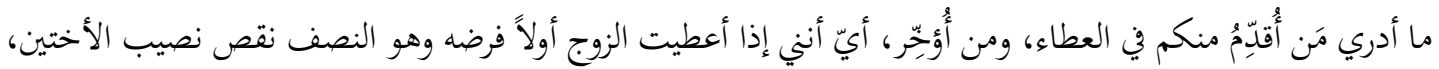

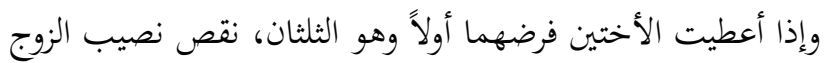

Artinya:

Berikanlah aku petunjuk, sesungguhnya ketika aku mendahulukan suami dan memberikan haknya secara utuh, maka dua saudari tidak dapat menerima hak mereka secara utuh. Begitu juga jika aku mendahulukan dua saudari dan memberikan bagian mereka secara utuh, maka suami tidak dapat menerima haknya. ${ }^{33}$

Hasil musyawarah mengeluarkan kebijakan 'aul sebagai solusi kasus tersebut yaitu dengan membebankan pengurangan bagian kepada tiap ahli waris secara merata tanpa mendahulukan atau mengakhirkan salah satu dari ahli waris. Al-Lāhim menyatakan bahwa yang memberikan pendapat tentang 'aul kepada 'Umar adalah 'Abbās bin Abdul Muțallib dalam suatu riwayat. Ada yang mengatakan bahwa yang memberikan pendapat adalah 'Ali bin Abi Țālib, dan sebagian ada yang mengatakan bahwa yang memberikan pendapat adalah Zaid bin Sabit, serta adapula yang mengatakan bahwa para sahabat berdiskusi mengenai 'aul dalam satu majelis, dan tentunya hal ini tidak sepantasnya dijadikan sebuah permasalahan karena tidak adanya hukum di dalamnya. ${ }^{34}$ Penyelesaian masalah dengan 'aul selanjutnya disepakati serta diikuti oleh jumhur sahabat dan empat mazhab. ${ }^{35}$ Contoh penyelesaian secara 'aul seperti yang disajikan pada tabel berikut.

Tabel 2

Konfigurasi Masalah Setelah 'Aul

\begin{tabular}{ccccc}
\hline Ahli Waris & $\begin{array}{c}\text { Bagian Ahli } \\
\text { Waris }\end{array}$ & $\begin{array}{c}\text { Asal masalah } \\
(6)\end{array}$ & $\begin{array}{c}\text { Asal masalah } \\
\text { setelah } \\
7\end{array}$ & $\begin{array}{c}\text { Harta Waisan } \\
(\mathrm{Rp} 42.000,00)\end{array}$ \\
\hline Suami & $1 / 2$ & $3 / 6$ & $3 / 7$ & Rp18.000,00 \\
\hline 2 Saudari & $2 / 3$ & $4 / 6$ & $4 / 7$ & Rp24.000,00 \\
\hline
\end{tabular}

Sumber: Data diolah (2021)

Jika harta yang ditinggalkan misalnya adalah Rp42.000.000, maka bagian suami adalah 3/7 x Rp42.000.000 yaitu Rp18.000.000,00, sementara bagian dua saudari adalah 4/7 x Rp42.000.000,00 yaitu Rp24.000.000,00. Dengan model penyelesaian secara 'aul seperti itu, maka bagian seluruh ahli waris terkurangi secara merata sesuai dengan proporsi dari ketentuan bagian fard masing-masing tanpa ada yang dizalimi. ${ }^{36}$

\footnotetext{
33 Ibid.

${ }^{34}$ Abdul Karīm Muhammad Al-Lāhim, Al-Farāiẹ, Cet. I (Riyad: Maktabah al-Ma’ārif, 1986), h. 26.

${ }^{35}$ Wahbah bin Mushtofa Al-Zuhaylî, Al-Fiqh Al-Islamî Wa Adillatuh, Juz 10, Cet. I (Damaskus: Dār al Fikr, 2002), h. 7821.

${ }^{36}$ Bachri, "Pro Kontra 'Aul Dalam Kewarisan Islam: Studi Komparatif Antara Pandangan Sunni Dan Syiah. ": 56.
} 


\section{Manhaj Istinbāt dan Implementasi 'Aul Menurut 'Umar bin al- Khațtāb}

'Umar bin al-Khatțāb merupakan salah seorang mujtahid yang memiliki banyak keutamaan, sehingga dijuluki sebagai al-Farūq (pembeda antara haq dan batil) tidak hanya bagi kaum muslimin tetapi juga bagi non muslim. Di masa kekhalifaannya, 'Umar bin Al-Khatțāb tidak hanya berhasil melakukan perluasan daerah kekuasaan Islam, namun juga menjalankan pemerintahan yang teratur melalui kecerdasannya. 'Umar terkenal banyak menyumbangkan pemikiran yang cemerlang dalam perkembangan hukum Islam. pemikiran-pemikiran 'Umar tertuang dalam ijtihadnya terhadap berbagai permasalahan yang muncul dan memiliki kemampuan untuk tetap memegang teguh tasyri' ketika situasi menginginkan terwujudnya sebuah kemaslahatan. ${ }^{37}$ Sikap tegas 'Umar bin al-Khaț̣āb dalam masalah agama bermuara pada aplikasi perintah agama dalam segala makna, dengan tetap berpedoman pada AlQur'an dan sunah dengan penuh kehati-hatian. ${ }^{38}$

Kualifikasi ijtihad 'Umar bin al-Khattāa muncul dari fikihnya yang luas dan konseptual. $^{39}$ Dalam perspektif usul fikih, ijtihad adalah instrumen yang mengharuskan seorang fakih untuk melakukan istinba $\underline{t}$ hukum dari sumbernya dengan segala kemampuannya untuk menghasilkan produk hukum. ${ }^{40}$ Semua syarat kualifikasi mujtahid sudah ada dan sempurna dalam diri 'Umar bin Al-Khatțāb. Ditambah alSyaukān̄ menyebutkan bahwa kecerdasan, penguasaan Al-Qur'an dan sunah, pemahaman terhadap ijmak dan kias, nāsikh dan mansūkh, dasar-dasar hukum, dan penguasaan bahasa Arab, semuanya tersedia dengan sempurna. ${ }^{41}$

'Umar sendiri adalah salah satu sahabat yang memiliki kualitas keilmuan yang sangat baik. Saat Rasulullah saw. masih hidup, pendapat-pendapat 'Umar tidak jarang langsung dibenarkan oleh Allah melalui firman-Nya, sebagai contoh ketika seorang munafik yang bernama 'Ubay bin Salūl meninggal dan Rasulullah ingin menyalatkan jenazahnya, maka 'Umar bangkit dan menyatakan pendapatnya tentang ketidaklayakan menyalatkan jenazah orang munafik yang merupakan musuh Allah, di mana setelah itu turun wahyu membenarkan apa yang disampaikan 'Umar. ${ }^{42}$ Walaupun demikian, sejatinya ijtihad 'Umar dalam mengaplikasikan syariat Islam baru dimulai setelah Rasulullah saw. wafat. Secara teori, konsep ijtihad 'Umar dapat kita lihat dalam pesan-pesan yang dikirimkannya kepada hakim yang diangkat dan ditugaskannya di berbagai daerah, ada dua surat yang secara historis dinisbatkan

${ }^{37}$ Muhammad Baltaji, Metode Ijtihad 'Umar Bin Al-Khațtāb (Jakarta: Khalifa, 2005), h. 3.

${ }^{38}$ Abdul Mukti Thabrani, "Ijtihad Politik Umar Ibn Al-Khattab (Implementasi Fiqh Kontekstual Dalam Pemerintahan Islam)," NUANSA: Jurnal Penelitian Ilmu Sosial Dan Keagamaan Islam 12, no. 2 (December 16, 2015): 283, doi:10.19105/NUANSA.V12I2.770.

39 Fahmi Jawwas, "Posisi Naṣ Dalam Ijtihad 'Umar Ibn Khațāā," HUNAFA: Jurnal Studia Islamika 10, no. 2 (December 15, 2013): 377, doi:10.24239/JSI.V10I2.36.359-379.

${ }^{40}$ Haḍari Beik, Tarikh Tasyri' Al-Islami, Cet. I (Kairo: Maktabah Tijāriyyah, 1970), h. 96.

${ }^{41}$ Muhammad bin Alī bin Muhammad Al-Syaukāni, Irsyādu Al-Fuhūl F̄̄ 'Ilmi Al-Ușūl, Cet. I (Beirut: Muassasah al-Rayyān, 2000), h. 250.

${ }^{42}$ Muhạmmad bin Ismā'il Al-Bukhārī, Șaḥịh Al-Bukhārī, Cet. I (Kairo: al-Dār al-'Alamiyyah, 2016), h. 307. 
kepada 'Umar, yaitu suratnya kepada Șuraỵ yang menjadi qāa $\bar{\imath}$ di Kufah dan Abu Mūsā al-Asy’arī yang menjadi qā dī di Bașrah. ${ }^{43}$

Dalam surat tersebut jelas sekali menggambarkan pemikiran 'Umar dalam berijtihad terhadap sebuah permasalahan. Di satu sisi 'Umar tetap berpegang kokoh pada nas yang ada, namun di sisi lain juga menjadikan maslahat sebagai pertimbangan penting dalam berijtihad, ${ }^{44}$ di samping 'Umar juga bersandar pada ijmak dan kias. Maksud ijmak di sini adalah kesepakatan orang-orang yang mengerti permasalahan yang dihadapi saat itu dan diikuti oleh orang-orang lain dengan menyetujuinya. Walaupun dari sisi beberapa istilah usul fikih belum dikenal pada masa 'Umar, seperti istilah sad al-żarāi, kias dan maṣlaḥah, namun istilah ini lahir karena dipraktikkan secara perbuatan oleh para sahabat sepeninggal Rasulullah saw., seperti ijtihad 'Umar tentang zakat 'urud al-tijārah yang dikiaskan pada zakat emas dan perak..$^{45}$ Dalam permasalahan suami dan dua orang saudari yang meminta pembagian warisan secara adil, 'Umar bin al-Khatțāb berkata,

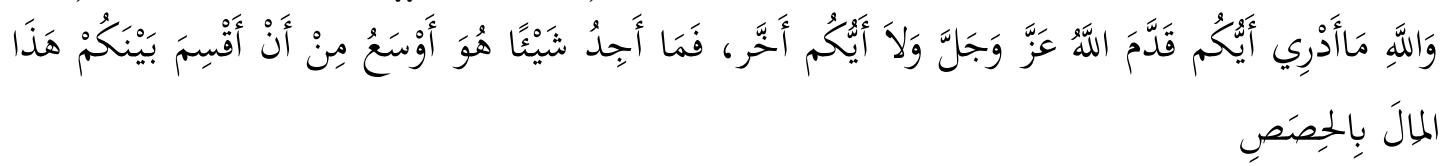

Artinya:

Demi Allah, aku tidak tahu siapa di antara kalian yang didahulukan dan diakhirkan Allah, dan aku tidak mendapati cara perhitungan yang lebih tepat untuk membagi harta ini di antara kalian. ${ }^{46}$

'Umar bin al-Khațāa kemudian memilih 'aul dalam menyelesaikan masalah berlandas pada hadis Rasulullah saw.,

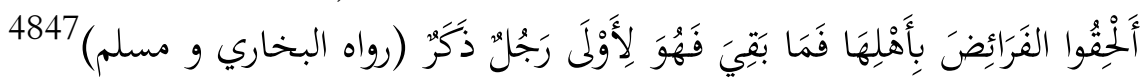

Artinya:

Berikan bagian warisan kepada ahli warisnya, selebihnya adalah milik laki-laki yang paling dekat.

Hadis di atas memerintahkan agar warisan diberikan kepada pemiliknya tanpa membedakan antar ahli waris. Selain itu, penyelesaian masalah menggunakan 'aul telah disepakati dan menjadi ijmak sebelum ada bantahan dari 'Abdullah bin 'Abbās. ${ }^{49}$ Ibnu Qudamah al-Maqdīsī mengatakan bahwa sampai saat ini tidak diketahui siapa yang menjadi pencetus di mazhab 'Abdullah bin 'Abbās, dan tidak diketahui juga siapa saja yang menyelisihi fuqahā dalam permasalahan 'aul. ${ }^{50}$ Begitu pun 'Umar bin alKhațāāb dalam menerapkan 'aul berangkat pada landasan kias. Pada dasarnya ahlul

43 Tasnim Rahman Fitra, "Ijtihad 'Umar Bin Al-Khațāa Dalam Perspektif Hukum Progresif," AlAhkam 26, no. 1 (April 14, 2016): 49, doi:10.21580/AHKAM.2016.26.1.705.

44 Ibid.

${ }^{45}$ Muhammad Rawwas Qal'ahji, Mausū'at Fiqh 'Umar Bin Al-Khațtāb, Cet. IV (Beirut: Dār alNafais, 1989), h. 453.

${ }^{46}$ Ahmad bin Husain Abū Bakr Al-Baihaq̄i, Al-Sunan Al-Kubra, Cet. III (Beirut: Dār al-Kutub alIlmiyyah, 2003), h. 253.

47 Abu al-Husain Muslim Al-Hajjāj, Al-Sunan Al-Baihaqī Al-Kubrāa, Cet. I (Kairo: al-Dār al'Alamiyyah, 2016), h 490.

${ }^{48}$ Al-Bukhārī, Șaḥịh Al-Bukhārī, h. 1668.

${ }^{49}$ Al-Faūzan, Al-Tahqūqātu Al-Mardiyyah Fi Al-Mabāḥis Al-Farḍyyah, h. 167.

${ }^{50}$ Al-Maqdisī, Al-Mugnī, h. 28. 
fard memiliki hak yang telah ditentukan dan memiliki kesamaan, maka apabila jumlah warisan tidak cukup untuk dibagi kepada seluruh ahli waris maka dipastikan adanya pengurangan pada tiap hak ahli waris sesuai bagiannya, seperti halnya dengan utang apabila jumlah harta tidak cukup untuk membayar semua utang, maka utang tersebut dibayar secara adil. ${ }^{51}$

Allah swt. telah menetapkan bahwa saudari kandung mendapat $1 / 2$ seperti halnya Allah menetapkan hak suami $1 / 2$ dan untuk 2 orang saudari kandung mendapat $2 / 3$ seperti halnya untuk 2 saudari seibu mendapat $1 / 3$. Tidak boleh ada pengurangan di salah satu ahli waris saja karena hak mereka telah ditetapkan oleh Allah swt., sehingga tidak mungkin terjadi ketidakseimbangan antara satu dengan yang lain. Maka untuk menerapkan keadilan dalam masalah ini wajib terjadi pengurangan di semua ahli waris seperti wasiat dan utang. ${ }^{52}$

Tabel 3

Konfigurasi Kias 'Aul Kepada Utang/Wasiat

\begin{tabular}{ccccc}
\hline Piutang & $\begin{array}{c}\text { Jumlah utang } \\
(\mathrm{Rp})\end{array}$ & persen & $\begin{array}{c}\text { Jumlah uang } \\
\text { mayyit (Rp) }\end{array}$ & $\begin{array}{c}\text { Utang yang dibayar } \\
(\mathrm{Rp})\end{array}$ \\
\cline { 1 - 3 } Piutang A & $\mathrm{Rp} 4.000 .000,00$ & $40 \%$ & & $\mathrm{Rp} 400.000,00$ \\
\cline { 1 - 3 } Piutang B & $\mathrm{Rp} 3.000 .000,00$ & $30 \%$ & \multirow{2}{*}{1.000 .000} & $\mathrm{Rp} 300.000,00$ \\
\cline { 1 - 3 } Piutang C & $\mathrm{Rp} 3.000 .000,00$ & $30 \%$ & & $\mathrm{Rp} 300.000,00$ \\
\hline
\end{tabular}

Sumber: Data diolah (2021)

Konfigurasi masalah ini, misalnya fulan meninggal dunia dan meninggalkan uang sebanyak Rp1.000.000,00, namun fulan memiliki utang sebanyak Rp10.000.000,00, maka utang ini dibagikan kepada piutangnya sesuai jumlah uang yang ditinggalkan yakni Rp1.000.000,00. Inilah yang menjadi landasan 'Umar bin alKhațāab dalam mengiaskan atau menyamakan permasalahan di atas dengan permasalahan 'aul, di mana masing-masing bagian ahli waris mengalami pengurangan pada jumlah harta yang didapat. Namun tidak semua masalah pada ilmu kewarisan disebut 'aul, kecuali memenuhi beberapa syarat diantaranya asal masalah harus termasuk asal masalah yang mengalami kenaikan ('aul) yakni asal masalah 6, 12 dan $24 .{ }^{53}$

${ }^{51}$ Ibrahīm bin 'Abdillah bin Ibrahim Al-Farḍ̄i, Al- 'Ażbu Al-Fāị Syarh 'Umdah Al-Fāiḍ, Cet. I (Beirut: Mațba'ah Muștafā al-Halbī, 1987), h. 163.

52 Al-Maqdisī, Al-Syarh Al-Kabìr “Ala Matan Al-Muqni.”, h. 31.

${ }^{53}$ Dib Fāṭimah, “Al-'Aul Wa Al-Rad Fī Al-Mawaris̀” Skripsi (Al-Bauirah: Fakultas Hukum dan Ilmu Politik Universitas Aklī Muhannadu au lihāj, 2015), h. 8. 
Tabel 4

Konfigurasi Masalah 'Aul Pada Asal Masalah 6

\begin{tabular}{cccc}
\hline Ahli waris & $\begin{array}{c}\text { Bagian ahli } \\
\text { waris }\end{array}$ & $\begin{array}{c}\text { Asal masalah: } \\
6\end{array}$ & $\begin{array}{c}\text { Asal masalah setelah } \\
\text { 'aul: } \\
9\end{array}$ \\
\hline Suami & $1 / 2$ & 3 & $3 / 9$ \\
\hline Saudari Kandung & $1 / 2$ & 3 & $3 / 9$ \\
\hline Saudari Seayah & $1 / 6$ & 1 & $1 / 9$ \\
\hline Saudari Seibu & $1 / 6$ & 1 & $1 / 9$ \\
\hline Ibu & $1 / 6$ & 1 & $1 / 9$ \\
\hline
\end{tabular}

Sumber: Data diolah (2021)

Syarat kedua yaitu tidak adanya 'așabah bilgaīr dari jalur anak (jihhatul bunuwwah, seperti anak perempuan bertemu dengan anak laki-laki, dan cucu perempuan dari anak laki-laki bertemu dengan saudara sederajatnya) ${ }^{54}$ maka tidak ada penambahan pada sihām, dan dipastikan tidak terjadi 'aul karena kehadiran 'așabah bilgaīr tersebut mengambil seluruh bagian harta warisan yang tersisa setelah dibagikan kepada ahli waris yang lain dan juga menghalangi ahli waris dari jalur saudara (jihhatul ukhuwwah)..$^{55}$ Terjadinya pengurangan pada jumlah warisan yang didapat oleh para ahli waris berdasarkan syarat terpenuhinya permasalahan 'aul, terjadi pada kadar warisan yang didapat oleh tiap ahli waris berdasarkan bagiannya dari jumlah harta warisan, dimana tidak ada perbedaan antara ahli waris serta tidak ada pengecualian di antara mereka. Seperti suami yang asalnya berhak mendapatkan $1 / 2$ bisa saja mendapatkan 1/3 dibeberapa keadaan, misal apabila terjadi 'aul dari asal masalah 6 ke 9, sehingga bagian suami pada awalnya berhak mendapat 3/6 atau 1/2 dari warisan, namun karena adanya 'aul sehingga mendapatkan $3 / 9$ atau 1/3 dari warisan. ${ }^{56}$

\section{Manhaj Istinbāt dan Implementasi 'Aul Menurut 'Abdullah bin 'Abbās}

'Abdullah bin 'Abbās cenderung menggunakan akal pikiran yang jernih dalam menafsirkan ayat Al-Qur'an, di mana cara seperti ini telah ditempuh sejak generasi kedua umat Islam. 'Abdullah bin 'Abbās dikenal berani berijtihad, dan diakui oleh kalangan sahabat, dan lebih cenderung menafsirkan ayat dari segi kebahasaan karena banyak merujuk kepada syair-syair Arab kuno atau percakapan orang-orang Badui yang memiliki tingkat kemurnian bahasa yang tinggi. Hal ini juga terlihat dari kitab tafsir yang memuat banyak riwayat penafsiran 'Abdullah bin 'Abbās di dalamnya. ${ }^{57}$

${ }^{54}$ Syamsu al-Dīn Al-Syarībīn̄i, Mugnī Al-Muḥtāj Ilā Ma'rifaḥ Ma'anī Al-Fāz Al-Manhāj, Juz 3, Cet. I (Beirut: Dār al-Ma'rifạ̣, 1997), h. 46.

55 'Abdullah bin Muhammad Ibnu Qudamah Al-Maqdis̄i, Al-Kāfì Fì Fiqh Imām Ahmad Bin Hanbal, Cet. I (Libanon: Dārul Kutub al-'Ilmiyyah, 1994), h. 35.

${ }^{56}$ Al-Maqdisī, Al-Syarh Al-Kabīr "Ala Matan Al-Muqni. ”, h. 472.

${ }^{57}$ Abu Țahir Muhammad bin Ya'qub Fairuz Abadi, Tanwīr Al-Maqbās F̄̄ Tafsìr Ibn 'Abbās, Cet. I (Beirut: Dār al-Kutub al-'Ilmiyyah, 1992), h. 21. 
'Abdullah bin 'Abbās menafsirkan ayat dengan ayat lain yang saling memiliki keterikatan makna dan saling menjelaskan satu sama lain. Jika penjelasan suatu ayat tidak ditemukan dalam ayat lain, 'Abdullah bin 'Abbās menafsirkannya dengan riwayat dari Rasulullah saw., sahabat, dan tabi' in, dan jika tidak ditemukan penjelasan dari ayat atau riwayat-riwayat lain, beliau menafsirkan suatu ayat dengan menggunakan nalar. ${ }^{58}$

Tabel 5

Penyelesaian Masalah Menurut 'Abdullah bin 'Abbās

\begin{tabular}{ccccc}
\hline Ahli waris & $\begin{array}{c}\text { Bagian ahli } \\
\text { waris }\end{array}$ & $\begin{array}{c}\text { Asal masalah } \\
6\end{array}$ & Penyelesaian & $\begin{array}{c}\text { Asal masalah } \\
6\end{array}$ \\
\hline Suami & $1 / 2$ & 3 & $1 / 2$ & 3 \\
\hline Saudari seibu & $1 / 6$ & 1 & $1 / 6$ & 1 \\
\hline $\begin{array}{c}\text { 2 Saudari } \\
\text { kandung }\end{array}$ & $2 / 3$ & 4 & 'așabah /sisa & 2 \\
\hline
\end{tabular}

Sumber: Data diolah (2021)

'Abdullah bin'Abbās adalah salah satu tokoh yang menolak adanya 'aul yang terjadi pada masa kekhalifaan 'Umar bin al-Khaț̣āb. 'Abdullah bin 'Abbās menolak 'aul karena berdalil bahwa penyelesaian masalah dengan menggunakan 'aul tidak sesuai dengan teks Al-Qur'an dan hadis serta tidak ada dalil yang jelas mengaturnya. Penolakan 'Abdullah bin 'Abbās baru muncul dengan tegas sepeninggal khalifah 'Umar bin al-Khațāâ, walaupun sebelumnya menolak namun tidak secara terangterangan.

Tabel 6

Penyelesaian Masalah al-Mubāhalaḥ Menurut 'Abdullah bin 'Abbās

\begin{tabular}{ccccc}
\hline Ahli waris & $\begin{array}{c}\text { Bagian ahli } \\
\text { waris }\end{array}$ & $\begin{array}{c}\text { Asal masalah } \\
6\end{array}$ & Penyelesaian & $\begin{array}{c}\text { Asal masalah } \\
6\end{array}$ \\
\hline Suami & $1 / 2$ & 3 & $1 / 2$ & 3 \\
\hline Ibu & $1 / 3$ & 2 & $1 / 3$ & 2 \\
\hline $\begin{array}{c}\text { Saudari } \\
\text { Kandung }\end{array}$ & $1 / 2$ & 3 & 'așabah $/$ sisa & 1 \\
\hline
\end{tabular}

Sumber: Data diolah (2021)

Pada saat dihadapkan dengan masalah al-mubāhalah, dengan jelas 'Abdullah bin 'Abbās menolak 'aul berlandaskan bahwa apa yang didahulukan atau diutamakan oleh Allah bagiannya maka wajib dilaksanakan, begitupun apa yang diakhirkan maka

${ }^{58}$ Mohammad Izdiyan Muttaqin, “Abdullah Bin Abbas Dan Perannya Dalam Penafsiran AlQur'an: Studi Tafsir Abdullah Bin Abbas Dalam Nuskhah Ali Bin Abi Tholhah," MISYKAT: Jurnal Ilmu-Ilmu Al-Quran, Hadist, Syari'ah Dan Tarbiyah 4, no. 2 (December 10, 2019): 59, doi:10.33511/MISYKAT.V4N2.59-86. 
wajib diakhirkan. Dalam arti bahwa ahlul furūẹ (ahli waris secara farḍ) mengalami peralihan bagian warisan namun tetap pada statusnya dan tetap menjadi ahlul fard. Ini yang dimaksud didahulukan atau diutamakan oleh Alah pembagiannya seperti ibu, suami, istri dan saudara seibu. Adapun bagi ahlul furū bagian warisan menjadi 'așabah (sisa) inilah yang dimaksud diakhirkan oleh Allah seperti saudari kandung dan saudari sebapak yang terkadang mendapat bagian secara fard dan terkadang mendapat sisa. Sehingga, yang didahulukan atau diutamakan bagiannya oleh Al-Qur'an akan diberikan haknya secara sempurna dan yang diakhirkan akan diberikan bagiannya sesuai apa yang tersisa dari warisan. ${ }^{59}$

\section{Analisis Komparatif Terhadap Pandangan Umar bin al-Khațțāb dan 'Abdullah bin 'Abbās dalam Permasalahan 'Aul}

Menghadapi masalah 'aul, 'Umar bin al-Khatțāb sebagai seorang sahabat yang pertama menggunakan teori ini menetapkan kebijakan hukum bahwa kekurangan bagian harta itu dibebankan kepada masing-masing yang berhak berdasarkan kadar perbandingan furü d mereka sehingga masing-masing hak mereka berkurang secara adil. ${ }^{60}$ 'Umar melakukan hal tersebut bedasarkan kapasitasnya sebagai seorang khalifah, di mana penguasa boleh menetapkan aturan dengan kekuasaannya seperti mewajibkan yang tidak wajib jika dipandang ada maslahat dalam kebijakan tersebut. ${ }^{61}$ Dasar kebijakan yang diambil Umar dalam masalah 'aul di atas adalah mempertimbangkan di antara dua hal, mana yang paling menguntungkan dan paling tinggi kemaslahatannya. ${ }^{62}$ Ini adalah sebuah kebijakan hukum yang diambil 'Umar bin al-Khațtāb karena berpatokan pada nas yakni hadis 'Abdullah bin 'Abbās, juga berdalil pada ijmak, kias serta mașlahạ mursalah.

Adapun 'aul menurut 'Abdullah bin 'Abbās berlandaskan pada kias, yang menyebutkan bahwa apabila harta tidak cukup untuk dibagi kepada seluruh ahli waris maka tentu yang paling kuat kedudukannya akan didahulukan, seperti al-tajhizz, utang, wasiat dan warisan. ${ }^{63}$ 'Abdullah bin 'Abbās beranggapan bahwa kias yang dijadikan landasan pada pendapat 'Umar bin al-Khatțāb yang menyebutkan bahwa harta warisan yang tidak cukup untuk ahlul furū jumlah harta yang didapat merupakan kias yang tidak sah, karena ahli waris (fard) memiliki kedudukan dan kadar harta yang harus diberikan tanpa dikurangi sedikit pun sesuai yang ditentukan. Namun, setiap ahli waris memiliki kedudukan yang berbeda dan yang diutamakan adalah yang paling kuat kedudukannya. Adapun yang mengiaskan ke utang maka ini pun tidak tepat menurut pendapat kedua. ${ }^{64}$ Apa yang Allah tetapkan untuk ahli waris yang selalu mendapatkan fard maka inilah yang

${ }^{59}$ Al-Faūzan, Al-Taḥqūqātu Al-Marḍiyyah Fi Al-Mabāḥis̀ Al-Farḍiyyah, h. 167.

${ }^{60}$ Elfia, "Kebijakan Hukum Dalam Penyelesaian Kewarisan Islam (Analisis Terhadap Beberapa Kebijakan Umar Bin Al-Khattab)," FOKUS Jurnal Kajian Keislaman Dan Kemasyarakatan 2, no. 2 (December 31, 2017): 127, doi:10.29240/JF.V2I2.296.

${ }^{61}$ Khaerul Aqbar and Azwar Iskandar, "Kontekstualisasi Ekonomi Zakat Dalam Mengentaskan Kemiskinan: Studi Kebijakan Zakat Umar Bin Khattab Dan Perzakatan Di Indonesia," Laa Maisyir : Jurnal Ekonomi Islam 6, no. 2 (2019): 236, doi:10.24252/LAMAISYIR.V6I2.11841.

${ }^{62}$ Elfia, "Kebijakan Hukum Dalam Penyelesaian Kewarisan Islam (Analisis Terhadap Beberapa Kebijakan Umar Bin Al-Khattab). ”: 127.

${ }^{63}$ Al-Lāhim, Al-Farāid, h. 28.

64 Ibid. 
didahulukan, adapun yang terkadang mendapatkan farḍ dan juga secara 'aṣabah inilah yang akan diakhirkan. ${ }^{65}$

Dari riwayat tersebut menjelaskan bahwa suami, istri, ibu dan nenek kedudukannya lebih kuat dibanding anak perempuan dan cucu perempuan dari anak laki-laki dan saudari perempuan. Hal ini menunjukkan bahwa suami, istri, ibu dan nenek lebih didahulukan oleh Allah dari anak perempuan, cucu perempuan dari anak laki-laki dan saudari kandung serta saudari seayah. ${ }^{66}$ Sama halnya dengan saudara seibu lebih kuat dibanding saudari kandung atau saudari seayah karena saudara seibu berpindah dari fard ke fard, berbeda dengan saudari kandung atau saudari seayah yang berpindah dari farḍ ke 'aṣabah. ${ }^{67}$

Tabel 7

Ahli Waris Yang Mendapat Bagian Secara Fard (Ahlul Furūd)

\begin{tabular}{|c|c|c|c|c|c|}
\hline $\begin{array}{l}\text { Ahli } \\
\text { waris }\end{array}$ & $\begin{array}{l}\text { Bagian } \\
\text { warisan }\end{array}$ & Syarat & $\begin{array}{c}\text { Perpindahan } \\
\text { bagian } \\
\text { warisan }\end{array}$ & Syarat & $\begin{array}{c}\text { status } \\
\text { perpindahan } \\
\text { bagian } \\
\text { warisan }\end{array}$ \\
\hline \multirow[b]{2}{*}{ Suami } & \multirow[b]{2}{*}{$1 / 2$} & $\begin{array}{l}\text { Tidak punya } \\
\text { anak }\end{array}$ & \multirow[b]{2}{*}{$1 / 4$} & Jika ada anak & \multirow[b]{2}{*}{ farḍ ke farḍ } \\
\hline & & $\begin{array}{l}\text { Tidak punya } \\
\text { cucu dari anak } \\
\text { anak laki-laki }\end{array}$ & & $\begin{array}{l}\text { Jika ada cucu } \\
\text { dari anak anak } \\
\text { laki-laki }\end{array}$ & \\
\hline \multirow[b]{2}{*}{ Istri } & \multirow[b]{2}{*}{$1 / 4$} & $\begin{array}{l}\text { Tidak punya } \\
\text { anak }\end{array}$ & \multirow[b]{2}{*}{$1 / 8$} & Jika ada anak & \multirow[b]{2}{*}{ fard ke fard } \\
\hline & & $\begin{array}{l}\text { Tidak punya } \\
\text { cucu dari anak } \\
\text { anak laki-laki }\end{array}$ & & $\begin{array}{l}\text { Jika ada cucu } \\
\text { dari anak anak } \\
\text { laki-laki }\end{array}$ & \\
\hline \multirow[b]{2}{*}{ Ibu } & \multirow[b]{2}{*}{$1 / 3$} & $\begin{array}{l}\text { Jika tidak ada } \\
\text { anak }\end{array}$ & \multirow[b]{2}{*}{$1 / 6$} & Jika ada anak & \multirow[b]{2}{*}{ farḍ ke farḍ } \\
\hline & & $\begin{array}{l}\text { Bersamanya } \\
\text { hanya satu } \\
\text { saudara mayyit }\end{array}$ & & $\begin{array}{l}\text { Ada dua atau } \\
\text { lebih saudara } \\
\text { mayyit }\end{array}$ & \\
\hline Nenek & $1 / 6$ & $\begin{array}{l}\text { Tidak ada ibu } \\
\text { dari mayyit }\end{array}$ & $1 / 6$ & $\begin{array}{l}\text { Tidak ada ibu } \\
\text { dari mayyit }\end{array}$ & fard ke fard \\
\hline \multirow{3}{*}{$\begin{array}{c}\text { Saudari } \\
\text { seibu }\end{array}$} & \multirow{3}{*}{$1 / 6$} & $\begin{array}{l}\text { Tidak ada anak } \\
\text { mayyit }\end{array}$ & \multirow{3}{*}{$1 / 3$} & $\begin{array}{l}\text { Tidak ada anak } \\
\text { mayyit }\end{array}$ & \multirow{3}{*}{ fard ke fard } \\
\hline & & $\begin{array}{l}\text { Tidak ada } \\
\text { bapak/kakek } \\
\text { mayyit }\end{array}$ & & $\begin{array}{l}\text { Tidak ada } \\
\text { bapak/kakek } \\
\text { mayyit }\end{array}$ & \\
\hline & & $\begin{array}{l}\text { Hanya dia } \\
\text { sendiri }\end{array}$ & & $\begin{array}{l}\text { Ada saudara } \\
\text { seibu yang lain }\end{array}$ & \\
\hline
\end{tabular}

Sumber: Data diolah (2021)

${ }^{65}$ Ibrahīm bin 'Abdillah al-Masyriqī Al-Madanī, Al-'Ażbu Al-Fāiḍ Syarh 'Umdah Al-Fārị̣ (Makkah: Ummu al-Qurā, 2020), h. 164.

${ }^{66}$ Ibid.

${ }^{67}$ Ibid. 
Uraian di atas sesuai dengan apa yang dikutip oleh Ibrāhīm al-Madānī bahwa sesungguhnya saudara seibu tidak akan mengalami pengurangan, begitupun dengan ahli waris yang tidak akan dihalangi ( hajb) kedudukannya lebih kuat dibanding yang kadang dihalangi. ${ }^{68}$ Dari sini diketahui bahwa apa yang berpindah dari fard ke fard maka tidak akan dihalangi oleh siapa pun, seperti suami, istri dan ibu, sehingga lebih kuat dari yang berpindah dari fard ke 'așabah seperti anak perempuan, cucu perempuan dari anak laki-laki, saudari kandung atau saudari seayah. Juga kedudukan saudari seibu lebih kuat dari kedudukan saudari kandung dan saudari seayah, karena berpindah dari fard ke fard sementara saudari kandung dan saudari seayah berpindah dari fard ke 'așabah. ${ }^{69}$

\section{Konsep dan Pandangan Jumhur dalam Men-tarjīh Permasalahan 'Aul}

Jumhur ulama menyelesaikan permasalahan kasus dengan cara yang sama antara satu kasus dengan kasus yang lain meskipun beberapa kasus diberikan namanama yang berbeda. Kesamaan penyelesaian tersebut dilakukan dengan menaikkan asal masalah atau penyebut untuk mengurangi bagian ahli waris secara merata. Alasan untuk mengurangi bagian ahli waris secara merata dikarenakan apabila tidak dikurangi, maka harta warisan tidak akan cukup untuk dibagi kepada seluruh ahli waris. Sementara itu jika mengurangi salah satu bagian ahli waris saja, tidak dilakukan karena tidak diketahui siapa yang harus didahulukan untuk mendapatkan bagian secara utuh dan siapa yang harus diakhirkan untuk dikurangi bagiannya sesuai ketentuan AlQur'an. Inilah yang menjadi alasan 'Umar bin al-Khatțāb menyelesaikan permasalahan dengan cara 'aul dan kemudian diikuti oleh sahabat dan jumhur ulama. ${ }^{70}$

Ahli farāiọ dari kalangan jumhur ulama merumuskan kemungkinankemungkinan keadaan yang memerlukan pemecahan secara 'aul yang didasarkan karena alasan jika dilakukan pembagian menurut ketentuan bagian fard, maka akan terjadi kekurangan harta waris untuk dibagikan kepada ahli waris. Beberapa kemungkinan itu dinyatakan dengan nama-nama tertentu seperti mubāhalah, gurrā, uтmu al-furukh, uтmu al-arāmil, mimbariyah, dan lain sebagainya. ${ }^{71}$ Sabiq juga menjelaskan cara pembagian warisan dengan menggunakan 'aul, mencari pokok masalah yang akan diselesaikan, kemudian menentuan bagian dari setiap ahli waris yang ada. Dari bagian tersebut terbentuklah asal masalah, dimana asal masalah dibagi berdasarkan jumlah yang didapat dari setiap ahli waris, sehingga akan terjadi pengurangan bagi setiap ahli waris sesuai dengan bagiannya. ${ }^{72}$

Penyelesaian masalah secara 'aul telah disepakati dan bahkan menjadi ijmak di antara sahabat, ${ }^{7374}$ sehingga tidak seorang pun dari kalangan sahabat yang mengingkarinya. Tetapi setelah masa khalifah 'Umar berlalu, muncul 'Abdullah bin Abbās dengan pendapat yang berbeda, akan tetapi pendapat tersebut tidak dapat

68 Ibid.

${ }^{69}$ Al-Lāhim, Al-Farāid, h. 28.

${ }^{70}$ Bachri, "Pro Kontra 'Aul Dalam Kewarisan Islam: Studi Komparatif Antara Pandangan Sunni Dan Syiah. ": 56.

${ }^{71}$ Amir Syarifuddin, Hukum Kewarisan Islam (Jakarta Timur: Prenada Media, 2004), h. 101.

${ }^{72}$ Sabiq, Fiqh Al-Sunnah, h. 633.

${ }^{73}$ Al-Șābūn̄̄, Al-Mawārī̀s Fù Al-Syarī’ati Al-Islāmiyyati, h. 100.

${ }^{74}$ Al-Fauzān, Al-Tahquīqātu Al-Marḍiyyah Fi Al-Mabāḥis Al-Farḍiyyah, h. 167. 
dijadikan pegangan karena dianggap menyalahi ijmak'. ${ }^{75}$ Pendapat 'Umar bin alKhatțāb mengenai permasalahan 'aul menjadi rujukan para jumhur ulama dari kalangan sahabat, tabi' in seperti 'Uṡmān, 'Alī, al- 'Abbās, Ibn Mas'ūd dan Zāid ra. Apabila siham bertambah atau mengalami kenaikan melebihi jumlah asal masalah atau terjadi kenaikan pada asal masalah, maka tiap ahli waris mendapatkan pengurangan jumlah harta yang didapat. Ini merupakan pendapat empat imam mazhab, yakni Hanafiah, Malikiyah, Syafi'iyah dan Hanabilah. ${ }^{76}$ Asumsi yang mengatakan bahwa 'aul dikiaskan kepada tajhīz, utang dan wasiat merupakan kias yang berbeda dan tidaklah sah, maka ini merupakan asumsi yang juga kurang tepat karena semuanya berkaitan dengan warisan yang diatur menurut kepentingan dan prioritas menurut para penolak 'aul, dan mengkhususkan sebagian ahli waris untuk dikurangkan warisannya tanpa ada dalil syar'i yang mengatur hal tersebut, maka ini adalah perbuatan batil. ${ }^{77}$

Tabel 8

Permasalahan Suami, Ibu dan 2 Saudara Seibu Menurut 'Abdullah bin 'Abbās

\begin{tabular}{ccc}
\hline Ahli Waris & Bagian Ahli Waris & Asal Masalah 6 \\
\hline Suami & $1 / 2$ & 3 \\
\hline Ibu & $1 / 3$ & 2 \\
\hline Saudara seibu & $1 / 3$ & 2 \\
\hline \multicolumn{3}{c}{ Jumlah } \\
\hline
\end{tabular}

Sumber: Data diolah (2021)

Anggapan yang mengatakan bahwa aturan pembagian warisan harus dibagi berdasarkan haknya secara sempurna tanpa ada pengurangan, merupakan anggapan yang kurang tepat kerena anak perempuan dan saudari bukanlah ahli waris yang diakhirkan, karena pemindahan dari fard ke sisa bukanlah sebab yang menjadikan kedudukan ahli waris tersebut lemah. Karena disisi lain ahli waris yang mendapatkan sisa kedudukannya juga kuat, seperti saudari yang kedudukannya lebih kuat dibanding ibu karena saudari yang jumlahnya lebih dari satu dapat mengurangi bagian harta untuk ibu dari 1/3 menjadi1/6 menurut ijmak, namun sebaliknya ibu tidak dapat mengurangi bagian harta yang untuk saudari. Begitupun anak perempuan lebih kuat kedudukannya dibanding suami atau istri karena anak perempuan dapat mengurangi bagian harta untuk suami ataupun istri dan sebaliknya suami ataupun istri tidak dapat mengurangi bagian harta untuk anak perempuan. Sehingga dalam hal ini dikatakan bagaimana mungkin ahli waris yang memiliki kedudukan yang lebih lemah yang akan diakhikan daripada yang kuat. ${ }^{78}$ Untuk menguatkan pendapat 'Umar bin al-Khaț̣āb

${ }^{75}$ Ahmad 'Aisyawi, Ahkam Al-Mawāriș Fì Syarī'at Al-Islāmiyaḥ, Cet. I (Kairo: Muṣtafa al-Bābī al-Halabī, 1969), h. 117.

${ }^{76}$ Syamsu al-Dīn Al-Sarkhasī, Al-Mabsūṭ (Libanon: Dār al-Ma'rifah, 1999), h. 161.

${ }^{77}$ Ibid, h. 162.

78 Ibid. 
maka dibuktikan dengan konfigurasi masalah suami, ibu dan saudara seibu pada Tabel 8 .

Apabila ahli waris terdiri dari suami, ibu, dan dua saudara seibu, maka ibu mendapatkan 1/6 karena adanya dua orang bersaudara dan tentunya ini tidak sesuai dengan mazhab 'Abdullah bin 'Abbās sendiri yang mengatakan bahwa 2 orang bersaudara tidak dapat menghalangi ibu mendapatkan 1/3, karena menurut 'Abdullah bin 'Abbās 2 orang bersaudara tidak dikatakan jamak, kemudian apabila ibu diberi 1/3, dua saudara seibu $1 / 3$ dan suami $1 / 2$, maka tentunya akan terjadi penambahan asal masalah ( 'aul) dari enam ke tujuh, maka di sini 'Abdullah bin 'Abbās dapat memilih penyelesaian masalah dengan menggunakan 'aul atau mengubah ketetapannya bahwa ibu dapat dihalangi oleh dua saudara, maka dari itu permasalahan tersebut disebut dengan permasalahan ilzām. Akan tetapi sebagian mengatakan mungkin saja 'Abdullah bin 'Abbās berijtihad dalam permasalahan ini dengan mengurangi bagian harta yang didapat oleh saudara seibu karena berpindah dari fard ke 'asabah apabila di halangi oleh ahli waris yang lain berbeda dengan ibu dan suami, ${ }^{79}$ namun ini tidaklah kuat sesuai pemaparan sebelumnya.

\section{Realitas Penerapan 'Aul di Indonesia}

Komari menyatakan bahwa untuk Negara Indonesia yang mayoritas menganut sistem kekerabatan parental atau bilateral para ahli hukum kekewarisan Islam Indonesia tentu pengembangannya atas dasar sistem kekerabatan parental atau bilateral, sedangkan Negara Arab atau timur tengah pada umumnya tentu dikembangkan atas dasar sistem kekerabatan patrilineal. ${ }^{80}$ Sebelumnya Komari menyatakan bahwa hingga saat ini pelaksanaan hukum waris di Indonesia lebih bercirikan kombinasi antara adat dan syariat. Hal ini tampak menjadi sikap ambivalen di kalangan masyarakat muslim, yang di satu sisi ingin menerapkan hukum waris Islam berdasarkan prinsip kewarisan menurut hukum syariat, tapi di sisi lain masih memegang teguh hukum adat. ${ }^{81}$

Hal ini diperkuat oleh pernyataan Assyafira bahwa pada pelaksanaannya termasuk dalam hal pewarisan, masyarakat dapat memilih hukum mana yang diberlakukan dalam suatu urusan keperdataan yang mereka miliki, antara hukum Islam, hukum perdata, atau hukum adat. ${ }^{82}$ Seperti penelitian yang dilakukan oleh Fikri dan Wahidin menemukan bahwa pada masyarakat Kelurahan Watang Bacukkiki, Sulawesi Selatan yang memberlakukan variasi dalam menjalankan hukum yang berurusan dengan keperdataan. Dalam hal pembagian harta waris, sebagian masyarakat tersebut membagikan warisan berdasarkan hukum adat sedangkan

\footnotetext{
${ }^{79}$ Al-Faūzan, al-Tahqūqātu al-Marḍiyyah Fi al-Mabāhịis al-Farḍiyyah, h. 167.

${ }^{80}$ Komari, "Penerapan Hukum Kewarisan Islam Di Indonesia," Mahkamah Agung Republik Indonesia; Direktorat Jenderal Badan Peradilan Agama, 2021, 12, https://badilag.mahkamahagung.go.id/artikel/publikasi/artikel/261.

${ }^{81}$ Komari, "Eksistensi Hukum Waris Di Indonesia: Antara Adat Dan Syariat," Asy-Syari'ah 17, no. 2 (September 2015): 173, doi:10.15575/as.v17i2.

${ }^{82}$ Gisca Nur Assyafira, "Wais Berdasakan Hukum Islam Di Indonesia," Al-Mashlahah Jurnal Hukum Islam Dan Pranata Sosial 8, no. 01 (May 26, 2020): 68, doi:10.30868/AM.V8I1.771.
} 
sebagian lainnya menggunakan hukum Islam. ${ }^{83}$ Begitupun penemuan Fauzi mengungkapkan bahwa pengaruh hukum waris Islam pada sebagian masyarakat Indonesia khususnya pada masyarakat Jawa dapat dilihat misalnya pada sistem pembagian warisan yang disebut dengan sapikul sagendong, konsep bagi waris yang menggabungkan hukum waris Islam dan adat. ${ }^{84}$

Kajian yang dilakukan Prasna tentang pembagian warisan di masyarakat Minangkabau juga menunjukkan bahwa pembagian warisan belangsung secara hukum Islam dan adat, dimana warisan terbagi menjadi dua jenis harta pokok, yaitu harta pusaka rendah dan pusaka tinggi. ${ }^{85}$ Lebih jauh Noviardi menjabarkan pembagian tersebut yaitu: Pertama, harta pusaka rendah, harta ini merupakan hasil pencarian bersama suami istri selama berkeluarga. Hukum kewarisan pada harta ini telah disepakati secara adat dan agama oleh ulama atau tokoh adat Minangkabau sendiri, bahwa pembagian waris pada harta ini sesuai dengan kaidah agama Islam dimana anak laki-laki mendapat dua berbanding satu dengan anak perempuan. Hal ini sudah menjadi ketetapan mutlak bagi adat Minangkabau mengingat falsafahnya "Adat basandi syarak, syarak basandi kitabullah" yang artinya adat harus tunduk pada aturan syariat. ${ }^{86}$ Kedua, harta pusaka tinggi berbeda dengan harta pusaka rendah, harta ini telah diwariskan atau telah dibagikan secara turun-temurun oleh nenek moyang Minangkabau sebelum Islam masuk di mana ada wasiat adat bahwa harta harus diberikan kepada anak perempuan karena perempuan memiliki derajat yang mulia di Minangkabau selain kodrat mereka yang lemah dari pada laki-laki. ${ }^{87}$

Basri mengungkapkan bahwa pelaksanaan pembagian harta waris dikalangan umat Islam, belum dilaksanakan sepenuhnya, hal ini tidak terlepas dari faktor-faktor yang mempengaruhi pola pemikiran maupun pola kehidupan sosial masyarakat yang sudah terpatri sejak jaman penjajan. Seperti halnya masyarakat Islam masih sangat bergantung dengan kebiasaan/adat dalam membagi harta warisan yang sangat bergantung pada pola kebijakan masing-masing yang satu sama lain berbeda-beda. ${ }^{88}$

Semakin jauhnya umat Islam dalam menerapkan hukum waris Islam yang sudah diatur dalam Al-Qur'an dan sunah salah satunya dipicu oleh adanya pemikiran menyimpang yang ingin beralih dari hukum syariat dalam pembagian harta warisan ke hukum buatan manusia. Seperti apa yang dikembangkan oleh Fauzi dalam mengungkap implikasi penelitiannya bahwa dalam rangka mewujudkan kebersatuan bangsa salah satunya hanya dapat dicapai melalui unifikasi hukum. Ide untuk

${ }^{83}$ Fikri \& Wahidin Fikri \& Wahidin, "Konsepsi Hukum Waris Islam Dan Hukum Waris Adat (Analisis Kontekstualisasi Dalam Masyarakat Bugis)," Al-Ahkam: Jurnal Ilmu Syari'ah Dan Hukum 2, no. 2 (2017): 203, doi:10.22515/al-ahkam.v2i2.500.

${ }^{84}$ Mohammad Yasir Fauzi, "Legislasi Hukum Kewarisan Di Indonesia," Ijtimaiyya: Jurnal Pengembangan Masyarakat Islam 9, no. 2 (2016): 74, doi:10.24042/IJPMI.V9I2.949.

${ }^{85}$ Adeb Davega Prasna, "Pewarisan Harta Di Minangkabau Dalam Perspektif Kompilasi Hukum Islam," Kordinat: Jurnal Komunikasi Antar Perguruan Tinggi Agama Islam 17, no. 1 (November 19, 2018): 32, doi:10.15408/kordinat.v17i1.8094.

${ }^{86}$ Adri Noviardi, "Harta Waris Pusaka Tinggi Adat Minangkabau Perspektif Maslahah Mursalah Asy-Syathibi," Sakina: Journal of Family Studies 4, no. 4 (December 31, 2020): 69, doi:http://urj.uinmalang.ac.id/index.php/jfs/article/view/610.

${ }^{87}$ Ibid.

${ }^{88}$ Saifullah Basri, "Hukum Waris Islam (Fara'id) Dan Penerapannya Dalam Masyarakat Islam," Jurnal Kepastian Hukum Dan Keadilan 1, no. 2 (2020): 44, doi:10.32502/jurnal\%20khdk.v1i2.2591. 
mempertahankan pluralitas hukum tentu saja tidak sejalan dengan cita-cita hukum yang sama untuk semua orang. Jika pluralitas hukum dipertahankan, tentu saja akan terjadi distorsi terhadap cita-cita persamaan hukum tersebut. Pada ranah yang lebih mendasar, tidak ada landasan konstitusional untuk membuat hukum yang berbedabeda yang diterapkan bagi golongan-golongan penduduk yang berbeda pula. ${ }^{89}$

Fauzi juga menyatakan bahwa upaya ke arah unifikasi dan kondifikasi hukum waris yang berlaku secara nasional seharusnya segera dimulai, di samping untuk menghindari konflik keluarga, memberikan kepastian hukum, juga sekaligus merupakan pembaruan terhadap hal-hal yang dianggap tidak adil dalam sistem hukum waris yang ada..$^{90}$ Bahwa penerapan atau pelaksanaan hukum kewarisan Islam dapat dilaksanakan dengan perdamaian atau islāh di antara para ahli waris, meskipun hasil perdamaian tersebut, tidak sama dengan norma-norma dalam Al-Qur'an sebagaimana disebut al-furū ḍ al-muqaddarah yaitu 1//2 (setengah), 1/4 (seperempat, 1/8 (seperdelapan) 1/3 (sepertiga), 1/6 (seperenam, dan 2/3 (dua pertiga). ${ }^{91}$

Penerapan atau pelaksanaan hukum kewarisan Islam dengan teori perdamaian (islāh) tersebut, secara tidak langsung juga menerapkan teori $i b r \bar{a}$ ', (membebaskan) sehingga diantara para ahli waris satu sama lain saling tolong menolong (ta'awun), baik teori ibra', dalam arti isqāt (menggugurkan) hak miliknya, maupun dalam arti tamlik, (menyerahkan) hak miliknya. Dengan demikian, penyelesaian harta kewarisan dengan perdamaian merupakan instrument yang baik untuk menjaga keutuhan hubungan keluarga, selain untuk menghindari atau menyelesaikan perselisian, perseteruan, bakan permusuhan. Sehingga akan terjaga kerukunan dan paguyuban kekerabatan atau kekeluargaan dalam masyarakat. ${ }^{92}$

Hal ini tentu tidak sejalan dengan konsep maqāṣid syarī'ah yang menuntun umat Islam untuk mematuhi hukum-hukum syariat sesuai Al-Qur'an dan sunah. Ini merupakan tanda yang sudah disampaikan oleh Nabi saw. dalam hadis yang diriwayatkan oleh Abu Hurairah,

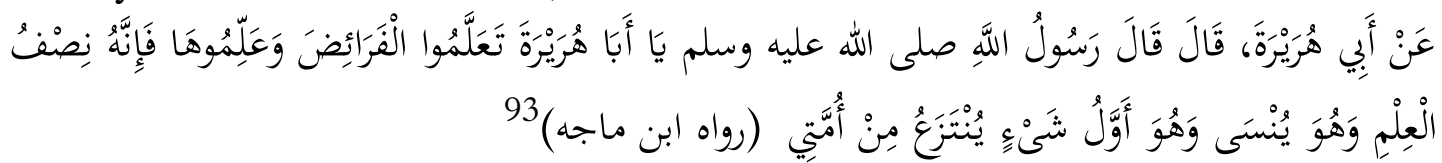

Artinya:

Dari Abi Hurāirah, bahwa Rasūlullah saw. bersabda, "Belajarlah ilmu farāị dan ajarkanlah, karena sesungguhnya ia adalah setengah dari ilmu. Dan ilmu itu akan dilupakan dan dia adalah ilmu yang pertama kali dicabut dari umatku."

Termasuk di dalamnya masalah penerapan 'aul yang kerap tidak diketahui oleh masyarakat Muslim secara teori akan tetapi tejadi secara fakta. Pada kasus biasa seperti meninggalnya seorang laki-laki atas istri dan anak kandung laki-laki dan perempuan saja masih banyak dijumpai kasus yang tidak menerapkan pembagian warisan sebagaimana yang diatur dalam Al-Qur'an, maka kasus yang lebih rumit dari itu

89 Mohammad Yasir Fauzi, "Legislasi Hukum Kewarisan di Indonesia," Ijtimaiyya: Jurnal Pengembangan Masyarakat Islam 9, no. 2 (2016): 75, doi:10.24042/IJPMI.V9I2.949.

${ }^{90}$ Mohammad Yasir Fauzi, 'Legislasi Hukum Kewarisan di Indonesi": 57.

${ }^{91}$ Komari, “Penerapan Hukum Kewarisan Islam Di Indonesia. ”: 157.

92 Ibid.

93 Al-Qazwīn̄̄, Sunan Ibnu Mājah, h. 462. 
seperti kasus 'aul akan lebih tidak bisa dipraktikkan sebagaimana tuntunan syariat dalam hal ini berupa apa yang telah disepakati oleh kaum muslimin.

Dalam memahami tradisi yang terjadi di tengah masyarakat Muslim Indonesia tersebut menurut Sayuti Thalib bahwa bagi orang Islam berlaku hukum Islam, hal tersebut sesuai dengan keyakinan dan cita-cita hukum dan cita-cita moral. Adapun hukum adat berlaku bagi orang Islam jika tidak bertentangan dengan agama Islam dan hukum Islam. ${ }^{94}$ Selama ini banyak masyarakat Indonesia yang kurang memahami tentang hak dan kewajiban ahli waris terhadap pewaris. Sejalan dengan ini, Hardiana dan Fahrana mengungkapkan bahwa di Indonesia permasalahan pembagian warisan sering kali menjadi sesuatu yang rumit, bahkan tak jarang menimbulkan pertikaian keluarga memperebutkan harta waris. Untuk itu, diperlukan suatu solusi pembagian waris yang adil untuk menyelesaikan persoalan warisan dan di dalam hukum Islam sudah ada solusinya..$^{95}$

Pemerintah dalam hal ini sebenarnya sudah melakukan upaya dalam mengarahkan masyarakat untuk kembali ke hukum Islam dengan menyediakan wadah untuk itu walaupun dinilai belum maksimal dalam pengupayaannya. Adanya Lembaga-lembaga atau komunitas-komunitas Islam juga ikut ambil peran dalam mengedukasi dan memudahkan masyarakat dalam penyelesaian pembagian warisan menurut syariat dengan menciptakan layanan bagi waris berbasis online. Begitupun pencerahan yang dilakukan baik melalui jalur pendidikan Islam, kajian-kajian atau melalui situs-situs tanya jawab pesoalan farāid. Semua upaya ini diharapkan mampu mengarahkan masyarakat muslim Indonesia kembali kepada tuntunan syariat dalam persoalan kewarisan.

\section{KESIMPULAN}

'Aul menurut 'Umar bin al-Khattāa dengan membagi risiko pengurangan bagian warisan kepada seluruh ahli waris karena pada dasarnya ahli fard memiliki hak yang telah ditentukan dan memiliki kesamaan. Apabila jumlah warisan tidak cukup untuk dibagi kepada seluruh ahli waris maka dipastikan adanya pengurangan pada semua bagian ahli waris tersebut. Adapun menurut 'Abdullah bin 'Abbās menyebutkan bahwa apabila harta tidak cukup untuk dibagi kepada seluruh ahli waris maka tentu yang paling kuat kedudukannya akan didahulukan. Hal ini disebabkan ahlul furū d memiliki kedudukan dan bagian harta yang harus diberikan tanpa dikurangi sedikit pun sesuai ketentuannya, namun setiap ahli waris tentunya memiliki kedudukan yang berbeda, dan yang diutamakan adalah yang paling kuat kedudukannya.

Jumhur ulama dalam hal ini lebih condong kepada pendapat 'Umar bin alKhaț̣āa dan menilai pendapat mazhab 'Abdullah bin 'Abbās sebagai pendapat syā $\dot{z}$ karena menyelisihi ijmak sahabat. Alasan untuk mengurangi bagian ahli waris secara merata dikarenakan apabila tidak dikurangi, maka harta waris akan tidak cukup untuk dibagikan kepada seluruh ahli waris. Sementara jika mengurangi salah satu bagian ahli

${ }^{94}$ Sayuti Thalib, Receptie a Contrario, Hubungan Hukum Adat Dengan Hukum Islam (Jakarta: Bina Aksara, 1980), h. 56.

95 Bella Hardiyana and Egi Fahrana, “Aplikasi Penerapan Syariat Islam Pada Pembagian Harta Warisan Berbasis Android," Jurnal Teknologi Dan Informasi 8, no. 1 (March 1, 2018): 30, doi:10.34010/JATI.V8I1.907. 
waris saja juga tidak ada ketentuannya dalam Al-Qur'an, begitupun dengan siapa yang harus diakhirkan untuk dikurangi bagiannya.

Adapun dari sisi penerapan pembagian warisan secara realitas di Indonesia dinilai masih jauh dari ketentuan syariat berupa apa yang telah disepakati oleh jumhur ulama. Hal ini dipicu oleh adanya hukum lain yang juga berkembang dan diterapkan oleh mayoritas masyarakat muslim Indonesia. Ditambah adanya faktor adat yang sudah menjadi kebiasaan turun temurun dalam ketentuan pembagian warisan dan dianggap tidak betentangan dengan syariat Islam. Mayoritas masyarakat tampak tidak terlalu memperhatikan masalah ini dengan serius dan lebih memilih menempuh jalur aman dengan menerapkan hukum adat. Maka penerapan 'aul secara khusus di Indonesia dapat dikatakan juga belum dipraktikkan secara maksimal dengan melihat realitas penerimaan dan penerapan hukum waris secara umum.

\section{DAFTAR PUSTAKA}

'Aisyawi, Ahmad. Ahkam Al-Mawāris̉ Fū Syarī'at Al-Islāmiyaḥ. Cet. I. Kairo: Muștafa al-Bābī al-Halabī, 1969.

Abadi, Abu Țahir Muhammad bin Ya'qub Fairuz. Tanwīr Al-Maqbās F̄̄ Tafsīr Ibn 'Abbās. Cet. I. Beirut: Dār al-Kutub al-'Ilmiyyah, 1992.

Al-Baihaqī, Ahmad bin Husain Abū Bakr. Al-Sunan Al-Kubra. Cet. III. Beirut: Dār alKutub al-Ilmiyyah, 2003.

Al-Bukhārī, Muḥammad bin Ismā'il. Șaḥ̄ḥ Al-Bukhārī. Cet. I. Kairo: al-Dār al'Alamiyyah, 2016.

Al-Damasyq̄̄̄, Abū zakariyā al-Nawawī. Raudatu Al-Ṭālibīn. Cet. I. Libanon: Dār Ibn Hazm, 2002.

Al-Farḍ̄ī, Ibrahīm bin 'Abdillah bin Ibrahim. Al- 'Ażbu Al-Fāiḍ Syarh 'Umdah Al-Fāiḍ. Cet. I. Beirut: Maṭba'ah Muștafā al-Halbī, 1987.

Al-Faūzan, Șaleḥ bin Faūzan bin Abdillah. Al-Tahqūqātu Al-Marḍiyyah Fi Al-Mabāḥis Al- Fardiyyah. Cet. I. Riyad: Maktabatu al-Ma'ārif li al-Nasyri wa al-taūzì', 1999.

Al-Hajjāj, Abu al-Husain Muslim. Al-Sunan Al-Baihaq̄i Al-Kubrā. Cet. I. Kairo: alDār al-'Alamiyyah, 2016.

Al-Hașkafī, Muhammad. Al-Dār Al-Mukhtār. Cet. I. Libanon: Dār al-Kutub al'Ilmiyyah, 2002.

Al-Lāhim, Abdul Karīm Muhammad. Al-Farāiḍ. Cet. I. Riyad: Maktabah al-Ma’ārif, 1986.

Al-Madanī, Ibrahīm bin 'Abdillah al-Masyriqī. Al- 'Ażbu Al-Fāiḍ Syarh 'Umdah AlFāriḍ. Makkah: Ummu al-Qurā, 2020.

Al-Maqdis̄̄, 'Abdurraḥmān bin Aḥmad Ibnu Qudamah. Al-Syarh Al-Kabīr "Ala Matan Al-Muqni. " Cet. I. Damaskus: Dār al-Kitāb al-'Arab̄i, 1989.

Al-Maqdisī, 'Abdullah bin Aḥmad bin Qudāmaḥ al-Hanbalī. Al-Mugnī. Cet. I. Arab Saudi: Dār 'Aalim al-Kutub, 1997.

Al-Maqdisī, 'Abdullah bin Muhammad Ibnu Qudamah. Al-Kāfì Fì Fiqh Imām Ahmad Bin Hanbal. Cet. I. Libanon: Dārul Kutub al-'Ilmiyyah, 1994.

Al-Qatțān, Mannā'. Tarikh Al-Tasyri' Al-Islāmī Al-Tasyri' Wa Al-Fiqh. Cet. IV. Riyad: Maktabatu al-Ma'ārif li al-Nasyri wa al-taūzì', 2012.

Al-Qazwīnī, Abū Abdillah Muhammad bin Yazīd Ibnu Mājah. Sunan Ibnu Mājah. Cet.

I. Kairo: Ibnul Jauzi, 2014. 
Al-Ṣābūn̄̄, Muḥammad 'Alī. Al-Mawārīis F̄̄ Al-Syarī'ati Al-Islāmiyyati. Cet. I. Kairo: al-Dār al-'Alamiyyah, 2016.

Al-Said, 'Abdul 'Aziz. Al-Ijtihad Wa Ri'ayat Al-Mașlahah. Cet. I. Riyad: Islamic University of IMBS Press, 1994.

Al-Sarkhasī, Syamsu al-Dīn. Al-Mabsūṭt. Libanon: Dār al-Ma'rifah, 1999.

Al-Syarībīn̄̄, Syamsu al-Dīn. Mugnī Al-Muhtāj Ilā Ma'rifah Ma'an̄̄ Al-Fāz AlManhāj. Cet. I. Beirut: Dār al-Ma'rifaḥ, 1997.

Al-Syaukāni, Muhammad bin Alī bin Muhammad. Irsyādu Al-Fuhūl F̄̄ 'Ilmi Al-Ușūl. Cet. I. Beirut: Muassasah al-Rayyān, 2000.

Al-Zuhaylî, Wahbah bin Mushtofa. Al-Fiqh Al-Islamî Wa Adillatuh. Cet. I. Damaskus: Dār al Fikr, 2002.

Aqbar, Khaerul, and Azwar Iskandar. "Kontekstualisasi Ekonomi Zakat Dalam Mengentaskan Kemiskinan: Studi Kebijakan Zakat Umar Bin Khattab Dan Perzakatan Di Indonesia." Laa Maisyir : Jurnal Ekonomi Islam 6, no. 2 (2019): 226-245. doi:10.24252/LAMAISYIR.V6I2.11841.

Assyafira, Gisca Nur. "Wais Berdasakan Hukum Islam Di Indonesia." Al-Mashlahah Jurnal Hukum Islam Dan Pranata Sosial 8, no. 01 (May 26, 2020): 68-81. doi:10.30868/AM.V8I1.771.

Bachri, Syabbul. "Pro Kontra 'Aul Dalam Kewarisan Islam: Studi Komparatif Antara Pandangan Sunni Dan Syiah.” Journal de Jure 10, no. 2 (December 30, 2018): 49-60. doi:10.18860/J-FSH.V10I2.6707.

Baltaji, Muhammad. Metode Ijtihad 'Umar Bin Al-Khattāab. Jakarta: Khalifa, 2005.

Basri, Saifullah. "Hukum Waris Islam (Fara'id) Dan Penerapannya Dalam Masyarakat Islam.” Jurnal Kepastian Hukum Dan Keadilan 1, no. 2 (2020): 37-46. doi:10.32502/jurnal\%20khdk.v1i2.2591.

Bāz, 'Abdu al-'Azīz bin 'Abdillah bin. Matan Al-Rahbiyyah Li Al-Imām Al-Rahbī Wa Fawāid Al-Jaliyyah F̄̄ Al-Mabāhisii Al-Farḍiyyah. Cet. V. Riyad: al-Riāsatu al'Āmma li al- Idārāti al-Buhuś al- 'Ilmiyyah wa al-Iftāu wa al-Da'watu wa alIrsyād, 1987.

Beik, Haḍari. Tarikh Tasyri’ Al-Islami. Cet. I. Kairo: Maktabah Tijāriyyah, 1970.

Elfia, Elfia. "Kebijakan Hukum Dalam Penyelesaian Kewarisan Islam (Analisis Terhadap Beberapa Kebijakan Umar Bin Al-Khattab)." FOKUS Jurnal Kajian Keislaman Dan Kemasyarakatan 2, no. 2 (December 31, 2017): 125-150. doi:10.29240/JF.V2I2.296.

Faḍlullah, Sayyid Muhammad Husaīn. Fiqh Al-Mawārīs Wa Al-Farāiḍ. Juz 1. Libanon: Dārul-Malāk, 2000.

Fāṭimah, Dib. "Al-'Aul Wa Al-Rad Fī Al-Mawaris̀." Universitas Aklī Muhannadu au lihāj, 2015.

Fauzi, Mohammad Yasir. "Legislasi Hukum Kewarisan Di Indonesia.” Ijtimaiyya: Jurnal Pengembangan Masyarakat Islam 9, no. 2 (2016): 53-76. doi:10.24042/IJPMI.V9I2.949.

Fikri \& Wahidin, Fikri \& Wahidin. "Konsepsi Hukum Waris Islam Dan Hukum Waris Adat (Analisis Kontekstualisasi Dalam Masyarakat Bugis)." Al-Ahkam: Jurnal Ilmu Syari'ah Dan Hukum 2, no. 2 (2017): 193-204. doi:10.22515/alahkam.v2i2.500.

Firdaus, Muhammad. "Pembaharuan Hukum Waris Islam Di Era Kontemporer." 
Istinbath: Jurnal Hukum Islam IAIN Mataram 14, no. 1 (2015): 111-132. doi:10.15408/istinbath.v17i1.8094.

Fitra, Tasnim Rahman. "Ijtihad 'Umar Bin Al-Khaț̣āb Dalam Perspektif Hukum Progresif." Al-Ahkam 26, no. 1 (April 14, 2016): 49-64. doi:10.21580/AHKAM.2016.26.1.705.

Fitriyati, Yusida. "Kedudukan Ashabah Dalam Kasus 'Aul Menurut Ibnu Abbas." Nurani: Jurnal Kajian Syari'ah Dan Masyarakat 14, no. 2 (2014): 1-12. doi:10.19109/NURANI.V14I2.106.

Hamādah, 'Abdul Ḥakīm. Al-Jāmi' Lil Aḥkām Al-Fiqh 'Alā Al-Mazāhib Al-Arba'ah. Cet. I. Libanon: Dār al-Kutub al- 'Ilmiyyah, 2000.

Hardiyana, Bella, and Egi Fahrana. "Aplikasi Penerapan Syariat Islam Pada Pembagian Harta Warisan Berbasis Android.” Jurnal Teknologi Dan Informasi 8, no. 1 (March 1, 2018): 25-32. doi:10.34010/JATI.V8I1.907.

Jawwas, Fahmi. "Posisi Naṣ Dalam Ijtihad 'Umar Ibn Khațāā." HUNAFA: Jurnal Studia Islamika 10, no. 2 (December 15, 2013): 359-379. doi:10.24239/JSI.V10I2.36.359-379.

Khairi, Muhammad. 'Ilm Al-Farāiẹ Wa-Al-Mawaris: Fi Al-Syari'ah Al-Islamiyyah Wa-Al-Qanūn Al-Suri, Ma'a Amțilah Wa-Masā'il 'amaliyah. Cet. I. Damaskus, 1978.

Komari. "Eksistensi Hukum Waris Di Indonesia: Antara Adat Dan Syariat." AsySyari'ah 17, no. 2 (2015): 157-173. doi:10.15575/as.v17i2.

—. "Penerapan Hukum Kewarisan Islam Di Indonesia." Mahkamah Agung Republik Indonesia; Direktorat Jenderal Badan Peradilan Agama, 2021, 1-21. doi:https://badilag.mahkamahagung.go.id/artikel/publikasi/artikel/penerapanhukum-kewarisan-islam-di-indonesia-oleh-dr-komari-sh-m-hum-261.

Manẓūr, Ibnu. Lisānu Al-Arab. Juz. 1. Kairo: Dār al-Ma'ārif, 1999.

Muttaqin, Mohammad Izdiyan. "Abdullah Bin Abbas Dan Perannya Dalam Penafsiran Al-Qur'an: Studi Tafsir Abdullah Bin Abbas Dalam Nuskhah Ali Bin Abi Tholhah." MISYKAT: Jurnal Ilmu-Ilmu Al-Quran, Hadist, Syari'ah Dan Tarbiyah 4, no. 2 (December 10, 2019): 59-86. doi:10.33511/MISYKAT.V4N2.59-86.

Noviardi, Adri. "Harta Waris Pusaka Tinggi Adat Minangkabau Perspektif Maslahah Mursalah Asy-Syathibi." Sakina: Journal of Family Studies 4, no. 4 (December 31, 2020): 57-71. doi:http://urj.uin-malang.ac.id/index.php/jfs/article/view/610.

Prasna, Adeb Davega, and Adeb Davega Prasna. "Pewarisan Harta Di Minangkabau Dalam Perspektif Kompilasi Hukum Islam.” Kordinat: Jurnal Komunikasi Antar Perguruan Tinggi Agama Islam 17, no. 1 (November 19, 2018): 29-64. doi:10.15408/kordinat.v17i1.8094.

Qal'ahji, Muhammad Rawwas. Mausū'at Fiqh 'Umar Bin Al-Khaț̣̄āb. Cet. IV. Beirut: Dār al-Nafais, 1989.

Sabiq, Sayyid. Fiqh Al-Sunnah. Cet. I. Libanon: Dār al Kitāb al 'Arabī, 1997.

Supiana. Metodologi Studi Islam. Cet. I. Bandung: PT. Remaja Rosdakarya, 2017.

Syahendra, Hulia. "Aul Dalam Teori Dan Praktek Hukum Waris Islam.” Jurnal Hukum Replik 6, no. 1 (March 1, 2018): 97-120. doi:10.31000/JHR.V6I1.1179.

Syaifullah, Muhamad, Abadi Manangin, Leni Dwi Nurmala, and Nurmin K Martam. "Pengalihan Atas Harta Warisan Di Indonesia." DiH; Jurnal Ilmu Hukum 16, no. 
2 (n.d.): 177-189. doi:https://doi.org/10.30996/dih.v16i2.3345.

Syamsuddīn Muhammad 'Arafah al-Dasūqī. Hāsyiyatu Al-Dasūqī 'ala Al-Syarḥi AlKabīr. Cet. I. Damaskus: Dāru ihyā al-kitab al-'Arabiyyah, 2002.

Syarifuddin, Amir. Hukum Kewarisan Islam. Jakarta Timur: Prenada Media, 2004.

Thabrani, Abdul Mukti. "Ijtihad Politik Umar Ibn Al-Khattab (Implementasi Fiqh Kontekstual Dalam Pemerintahan Islam)." NUANSA: Jurnal Penelitian Ilmu Sosial Dan Keagamaan Islam 12, no. 2 (December 16, 2015): 259-284. doi:10.19105/NUANSA.V12I2.770.

Thalib, Sayuti. Receptie a Contrario, Hubungan Hukum Adat Dengan Hukum Islam. Jakarta: Bina Aksara, 1980.

Yahia, Fahd bin Abdirrahman. "Al-'Aul F̄̄ Al-Farāị̣ Fiqhan Wa Hisāban.” Qassim University-Saudi Arabia 6, no. 2 (n.d.): 103-128. doi:https\%3A\%2F\%2Fiefpedia.com\%2Farab\%2Fwp.

Zafr Ahmad al-'Uṡmānī al-Tahānawiyyu. I'lau Sunan. Cet. III. Idārah al-Qurān wa al'Ulūm al-Islāmiyyah, 1993. 